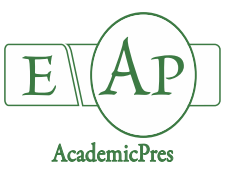

Abdel Latef AA et al. (2021)

Notulae Botanicae Horti Agrobotanici Cluj-Napoca

Volume 49, Issue 1, Article number 12192

DOI: $10.15835 /$ nbha49112192

Research Article

\title{
Mitigation of salinity stress by exogenous application of cytokinin in faba bean (Vicia faba L.)
}

\author{
Arafat A. ABDEL LATEF ${ }^{1 *}$, Md. HASANUZZAMAN², \\ Md. TAHJIB-UL-ARIF ${ }^{3}$
}
${ }^{1}$ Taif University, Turabah University College, Department of Biology, Turabah Branch, P.O. Box 11099, Taif 21944, Saudi Arabia; a.moawd@tu.edu.sa ("corresponding author);moawad76@gmail.com
${ }^{2}$ Bangladesh Agricultural University, Department of Biotechnology, Mymensingh 2202, Bangladesh; hasanbge50450@bau.edu.bd
${ }^{3}$ Bangladesh Agricultural University, Department of Biochemistry and Molecular Biology, Mymensingh 2202, Bangladesh; tahjib@bau.edu.bd

\begin{abstract}
Soil salinity limits agricultural land use and crop productivity, thereby a major threat to global food safety. Plants treated with several phytohormones including cytokinins were recently proved as a powerful tool to enhance plant's adaptation against various abiotic stresses. The current study was designed to investigate the potential role of 6-benzyladenine (BA) to improve broad bean (Vicia faba L.) salinity tolerance. The saltstressed broad bean plantlets were classified into two groups, one of which was sprayed with water and another was sprayed with $200 \mathrm{ppm}$ of BA. Foliar applications of BA to salt-exposed plants promoted the growth performance which was evidenced by enhanced root-shoot fresh and dry biomass. Reduced proline was strongly connected to the enhanced soluble proteins and free amino acids contents, protecting plant osmotic potential following BA treatment in salt-stressed broad bean. BA balanced entire mineral homeostasis and improved mineral absorption and translocation from roots to shoots, shoots to seeds and roots to seeds in salt-stressed plants. Excessive salt accumulation increased malondialdehyde level in leaves creating oxidative stress and disrupting cell membrane whereas BA supplementation reduced lipid peroxidation and improved oxidative defence. BA spray to salinity-stressed plants also compensated oxidative damage by boosting antioxidants defence mechanisms, as increased the enzymatic activity of superoxide dismutase, catalase, peroxidase and ascorbate peroxidase. Moreover, clustering heatmap and principal component analysis revealed that mineral imbalances, osmotic impairments and increased oxidative damage were the major contributors to salts toxicity, on the contrary, BA-augmented mineral homeostasis and higher antioxidant capacity were the reliable markers for creating salinity stress tolerance in broad bean. In conclusion, the exogenous application of BA alleviated the antagonistic effect of salinity and possessed broad bean to positively regulate the osmoprotectants, ion homeostasis, antioxidant activity and finally plant growth and yield, perhaps suggesting these easily-accessible and eco-friendly organic compounds could be powerful tools for the management of broad bean growth as well as the development of plant resiliency in saline prone soils.
\end{abstract}

Keywords: antioxidants; cytokinins; faba bean; oxidative stress; salt stress; 6-benzyladenine

Received: 14 Dec 2020. Received in revised form: 28 Feb 2021. Accepted: 02 Mar 2021. Published online: 09 Mar 2021.

From Volume 49, Issue 1, 2021, Notulae Botanicae Horti Agrobotanici Cluj-Napoca journal will use article numbers in place of the traditional method of continuous pagination through the volume. The journal will continue to appear quarterly, as before, with four annual numbers. 


\section{Introduction}

Faba bean (Vicia faba L.) or broad bean is one of the major legume crops belonging to the family Fabaceae that can grow across various meteorologic conditions (Singh et al., 2013; Abdel Latef et al., 2018). Vicia faba is a preferable and alternative source of essential proteins so that it is cultivated for collecting seeds that are consumed as human and animal feed. Along with high protein content and a balanced amino acids profile (nearly $30 \%$ of lysine), broad bean seeds are abundant in dietary fiber, minerals, vitamins, lipids, $\gamma$ aminobutyric acid and phenolic compounds which provides nourishment for humans and positively influence the antioxidant system and biological process (Giménez et al., 2012; Raikos et al., 2014; Mahdi et al., 2021). It can be grown in a wide range of agro-ecosystem, but the performance of this legume crop is severely affected because of several environmental stresses including salinity.

Soil salinity is considered as one of the primary abiotic stress factors associated with the significant economic impact because of losing a huge amount of agricultural land and declining crop yield (Mbarki et al., 2018; Fariduddin et al., 2019; Abdel Latef et al., 2020a). It was reported that over 800 Mha lands are saltcontaminated globally (Munns and Tester, 2008; Osman et al., 2020). Therefore, nowadays, salinity is a major threat to sustainable agricultural productivity. Further to this, about $45 \mathrm{Mha}$ of irrigated land are captured by salt stress-related problems worldwide, and more than $50 \%$ of arable land could be salt-affected by the next 30 years (Shrivastava and Kumar, 2015). Global soil salinization is aggravating day by day due to global warminginduced sea-level rise, saline-enriched water irrigation, and massive erosion of soils (Shrivastava and Kumar, 2015; Nachshon, 2018). The world population has been estimated to increase by about 2 billons in the next 30 years (DESA, 2015). Therefore, scientists are working to find economically feasible and efficient tactics to reduce or mitigate salt-induced stress for ensuring the nutritional security of the ever-increasing population (Geist, 2017; Noreen et al., 2020; Abdel Latef et al., 2021).

In crop plants, salinity stress inhibits the molecular, biochemical and physiological processes of crop plants by damaging photosynthetic activity, changing the osmotic adjustment and ionic homeostasis, producing toxic oxidants and radicals, regulating phytohormonal functions, counteracting essential metabolic pathways, and manipulating the gene expression pattern (Tang et al., 2015; Yang and Guo, 2018; Morton et al., 2019). Additionally, excess amounts of $\mathrm{Na}^{+}$and $\mathrm{Cl}^{-}$causes ionic imbalance, osmotic stress, water deficiency, and nutrient (such as $\mathrm{K}, \mathrm{Ca}, \mathrm{Mg}, \mathrm{Fe}, \mathrm{Zn}, \mathrm{N}$ and $\mathrm{P}$ ) disorders, which consequence in the physiological malfunction in both crop and vegetable plants (Rehman et al., 2019). However, excessive reactive oxygen species (ROS) generation due to the disruption of redox homeostasis leads to oxidative stress to the cellular biomolecules (Abdel Latef et al., 2017a,b,c, 2018, 2019a,b, 2020b; Attia et al., 2021). The plant showed a response against either osmotic or ionic stress in two mechanisms. In response to osmotic stress, the water absorption in plant root is inhibited that suppresses the cell development and growth of lateral bud, while ionic stress induces the change in the optimum ratios of $\mathrm{K}^{+} / \mathrm{Na}^{+}$content and $\mathrm{Na}^{+}$and $\mathrm{Cl}^{-}$ion levels that are detrimental for the normal cellular functions and processes (Munns and Tester, 2008; Singh et al., 2017). In stressed condition, plant defense against excessive ROS is associated with the protection of cellular redox homeostasis, which is mostly conferred by some antioxidant enzymatic activity for example superoxide dismutase (SOD), peroxidase (POD), catalase (CAT), and ascorbate peroxidase (APX), etc. (Tang et al., 2015; Tanveer and Shabala, 2018; Abdel Latef et al., 2020c; Rahman et al., 2020; Dawood et al., 2021). Therefore, any mechanisms that maintain optimal $\mathrm{K}^{+} / \mathrm{Na}^{+}$content, nutritional balance, and $\mathrm{ROS}$ in plants may provide tolerance capability against salinity (Assaha et al., 2017).

Different mitigation and adaptation approach was applied to conquer the adverse impacts of salt stress (Wang et al., 2019). Application of exogenous growth regulators including cytokinins (CK) would be an effective and affordable strategy for the development of plant resiliency against the detrimental consequences of salt stress. However, 6-benzyladenine (BA) is a CK-like plant growth regulator that can significantly amplify plant CK levels. It is reported that CK helps plants to confer salt tolerance by raising the activity of antioxidant enzymes and alleviating lipid peroxidation to protect the generation and scavenging consistency of ROS 
(Adam et al., 1989; Bin et al., 2010; Xiaotao et al., 2013). At present, applications of exogenous CK including BA have been described in mitigating various abiotic stresses, e.g salinity, drought, cold and waterlogging (Abdel-Latef, 2003; Azooz et al., 2004a,b; Iqbal et al., 2006; Abdel Latef et al., 2009; Javid et al., 201 1b; Wu et al., 2014; $\mathrm{Hu}$ et al., 2020). Therefore, the present investigation was operated for exploring the ameliorate role of BA for mitigating salt stress and promoting salt tolerance mechanism in broad bean plants by evaluating the following properties: (i) growth-promoting characters and yield, (ii) regulation of mineral homeostasis and translocation, (iii) level of osmoprotectants, (iv) oxidative stress and lipid peroxidation, (v) improvement of antioxidant enzymatic activity.

\section{Materials and Methods}

\section{Plant materials and experimental design}

The investigation was performed using broad bean (Vicia faba L. cv. 'Assiut 85/37'). Mature seeds were carefully surface-sterilized for $5 \mathrm{~min}$ in $0.1 \%$ mercuric chloride followed by three times washed with autoclaved distilled water. Then 10 disinfected seeds were planted in each pot where each pot was filled with $5 \mathrm{~kg}$ of airdried soil (sand: clay, 3:1 v/v). The pots were daily irrigated with tap water until full germination. On the $14^{\text {th }}$ day after sowing, germinated broad bean plantlets were subjected to $0 \mathrm{mM} \mathrm{NaCl}$ (control, C), $60 \mathrm{mM} \mathrm{NaCl}$ (S1), and $150 \mathrm{mM} \mathrm{NaCl}$ (S2) stress. After that, all pots were classified into 2 groups, one of which was sprayed with water and another was sprayed with 200 ppm of BA (Sigma-Aldrich, St. Louis, MI, USA) (50 mL to each pot at the 14-day interval for the total period of 100 days). Thus, there were six treatment compositions as follows: (i) control (C), $0 \mathrm{mM} \mathrm{NaCl}+0$ ppm BA; (ii) $60 \mathrm{mM} \mathrm{NaCl}+0$ ppm BA, S1; (iii) $60 \mathrm{mM} \mathrm{NaCl}+0$ ppm BA, S2; (iv) $0 \mathrm{mM} \mathrm{NaCl}+200 \mathrm{ppm} \mathrm{BA}, \mathrm{BA}$; (v) $60 \mathrm{mM} \mathrm{NaCl}+200 \mathrm{ppm} \mathrm{BA}, \mathrm{B}+\mathrm{S} 1$; and (vi) $150 \mathrm{mM}$ $\mathrm{NaCl}+200 \mathrm{ppm} \mathrm{BA}, \mathrm{B}+\mathrm{S} 2$. The dose of exogenous BA $(200 \mathrm{ppm})$ was selected as following the report of (Iqbal et al., 2006). Our investigations were conducted in a completely randomized design (CRD) with three replications where each pot containing 6 broad beans were considered as a replica.

\section{Plant growth measurements}

The root fresh weight (RFW), shoot fresh weight (SFW), fresh seed weight (FSW) and the number of nodules were estimated for determining the plant growth performance. The freshly harvested samples were packed and preserved in an aerated oven for 7 days at $80^{\circ} \mathrm{C}$. After that, the samples were completely desiccated and the root dry weight (RDW), shoot dry weight (SDW) and dry seed weight (DSW) were measured.

\section{Determination of mineral ion contents}

Root, stem and leaves were harvested from broad bean plant and rinsed these samples with deionized water for making them contamination-free. After that, fresh samples were dried in the oven for four days at 70 ${ }^{\circ} \mathrm{C}$. Then finely grinded plant samples were treated with $\mathrm{HNO}_{3}: \mathrm{HClO}_{4}(2: 1 \mathrm{v} / \mathrm{v})$ for $2 \mathrm{~h}$ at $220^{\circ} \mathrm{C}$ by following the protocol of (Williams and Twine, 1960). $\mathrm{Na}^{+}$and $\mathrm{K}^{+}$contents were determined by the atomic absorption flame spectrophotometer (Model AA-6400 F, Shimadzu Corporation, Japan). The versene (disodium dihydrogen ethylene-diamine-tetraacetic acid) titration method (Schwarzenbach and Biedermann, 1948) was used for $\mathrm{Ca}^{2+}$ and $\mathrm{Mg}^{2+}$ contents were estimated using the versene (disodium dihydrogen ethylene-diaminetetraacetic acid) method of titration. The level of translocation was determined from quantifying the value of translocation factor of nutrients in broad bean plant parts according to the procedure of (Hawrylak-Nowak, 2013):

Translocation factor (roots to shoot) $=$ Mineral content in shoot $/$ Mineral content in root

Translocation factor (shoot to seed) $=$ Mineral content in seed/Mineral content in shoot

Translocation factor (roots to seed) $=$ Mineral content in seed/Mineral content in root 


\section{Extraction and determination of antioxidant enzymatic activity}

The enzyme extraction was performed according to the procedure of (Mukherjee and Choudhuri, 1983). The fresh leaf samples $(0.2 \mathrm{~g})$ were finely ground in a cold mortar-pestle with $5 \mathrm{~mL}$ of $100 \mathrm{mM}$ potassium-phosphate of (K-P) buffer $\left(100 \mathrm{mM}, \mathrm{pH}\right.$ 7.0) having $\mathrm{Na}_{2}$ EDTA $(0.1 \mathrm{mM})$ and polyvinylpyrrolidone $(0.1 \mathrm{~g})$. Then, the homogenate was then filtered using cheesecloth and performed centrifugation at $12000 \times \mathrm{g}$ for $10 \mathrm{~min}$ at $4^{\circ} \mathrm{C}$ and the resulted supernatant was used for the analysis of the following antioxidants: superoxide dismutase (SOD; EC 1.15.1.1), catalase (CAT; EC 1.11.1.6), peroxidase (POD; EC 1.11.1.7) and ascorbate peroxidase (APX; EC 1.11.1.11).

The SOD activity was estimated as followed by the protocol of (Scebba et al., 1999). Leaf extracts (2 $\mathrm{mL}$ ) were added with the mixtures containing K-P buffer $(50 \mathrm{mM}$, pH 7.8), EDTA (0.1 mM), M L-methionine $(13 \mathrm{mM})$, riboflavin $(2 \mu \mathrm{M})$ and nitroblue tetrazolium $(75 \mu \mathrm{M})$ at a final volume of $3 \mathrm{~mL}$. The reaction was initiated, when the reaction mixtures were exposed to fluorescent light (cool white) for $15 \mathrm{~min}$. The blue reaction colour was determined spectrophotometrically at $560 \mathrm{~nm}$. The activities of CAT were assayed in 3 $\mathrm{mL}$ reaction solution comprised of K-P buffer $(50 \mathrm{mM}, \mathrm{pH} 7.0), \mathrm{H}_{2} \mathrm{O}_{2}(30 \%, \mathrm{w} / \mathrm{v})$ and leaf extract $(0.1 \mathrm{~mL})$, by using the method of (Aebi, 1984). The enzymatic activity of the CAT was determined by reducing of absorbance at $240 \mathrm{~nm}$ resultant in $\mathrm{H}_{2} \mathrm{O}_{2}$ consumption. POD activity was determined by adding leaf extract $(0.5 \mathrm{~mL})$ in $3 \mathrm{~mL}$ reaction mixture of K-P buffer $(10 \mathrm{mM}, \mathrm{pH} 7.0), \mathrm{H}_{2} \mathrm{O}_{2}(10 \mathrm{mM})$ and guaiacol $(20 \mathrm{mM})$ (Maehly and Chance, 1954). An increased absorbance as a consequence of the production of tetraguaiacol was observed at $470 \mathrm{~nm}$ (Klapheck et al., 1990). The activity of APX was determined from the decreased absorbance at $290 \mathrm{~nm}$ as ascorbic acid was oxidized (Chen and Asada, 1992). APX was assayed with the reaction mixtures $(3 \mathrm{~mL})$ having K-P buffer $(50 \mathrm{mM}, \mathrm{pH} 7.0)$, ascorbic acid $(0.5 \mathrm{mM})$ and $\mathrm{H}_{2} \mathrm{O}_{2}(0.5 \mathrm{mM})$. All spectrometric readings were taken through a Spectronic Genysis ${ }^{1 \mathrm{M}} 2 \mathrm{PC}$ spectrophotometer, Spectronic Instruments, USA.

\section{Measurement of lipid peroxidation}

The amounts Lipid peroxidation determined in the term of malondialdehyde (MDA) in broad bean followed by the protocol of (Heath and Packer, 1968). Leaves materials $(0.2 \mathrm{~g})$ were homogenized with the solutions of $5 \mathrm{~mL}$ of $5 \%$ trichloroacetic acid (TCA) followed by centrifuging at $15000 \mathrm{~g}$ for $10 \mathrm{~min}$ at $4{ }^{\circ} \mathrm{C}$. Along with $20 \%$ TCA, $4 \mathrm{~mL}$ solutions of $0.5 \%$ were added in $2 \mathrm{~mL}$ aliquots of the supernatant. The supernatant absorption and the non-specific absorption value were quantified at 532 and $600 \mathrm{~nm}$, respectively. The MDA contents were estimated by employing the absorption coefficient of $155 \mathrm{nmol}^{-1} \mathrm{~cm}^{-1}$.

\section{Measurement of proline, soluble sugars, soluble proteins and free amino acids levels}

The levels of proline (Pro) in broad bean plants were determined according to the description of (Bates et al., 1973). The method based on anthrone-sulfuric acid, as described by (Fales, 1951) was employed to determine the content of soluble sugars (SS). The method of (Lowry et al., 1951) was used to estimate soluble proteins (SP) content as following the standard of bovine serum albumin (BSA). The content of free amino acids (FAA) was estimated as following the procedure of (Moore and Stein, 1948).

\section{Statistical analysis}

The obtained data were undertaken to a two-way analysis of variance (ANOVA) followed by performing Tukey's test $(P<0.05)$ using the 'multcompView' package of the statistical programming language $\mathrm{R}$ 3.6.1. The MetaboAnalyst (https://www.metaboanalyst.ca/) was used for constructing heatmap and hierarchical clustering considering Euclidean distances. The packages 'ggplot2', 'factoextra', 'FactoMineR' of R 3.6.1 were used to perform principal component analysis (PCA). 


\section{Results}

\section{Analysis of variance}

The ANOVA of different growth and yield-contributing traits in the broad bean is shown in Supplementary Table 1 . The $S$ and BA significantly affect all growth and yield-related parameters in broad bean. However, $S$ and BA interaction has no significant difference on SDW and No. of nodules. The analysis of variance of SS, SP, proline, and FAA content in root, shoot and seed of broad bean is shown in Supplementary Table 2 . The $S$ and BA significantly affect SS, SP and FAA content in root, shoot and seed of broad bean plants. However, there is no significant difference was exhibited for $S$ and BA interaction with SP and FAA contents in root, SS content in shoot, SP and FAA contents in the seed of broad bean. The analysis of variance of different mineral content in root, shoot and seed of broad bean is shown in Supplementary Table 3. The $S$ and BA significantly affect $\mathrm{Na}^{+}, \mathrm{K}^{+}, \mathrm{Ca}^{2+}$ and $\mathrm{Mg}^{2+}$ contents in root, shoot and seed of broad bean plants. However, there is no significant difference was exhibited for $\mathrm{S}$ and $\mathrm{BA}$ interaction with $\mathrm{Mg}^{2+}$ content in root, $\mathrm{Na}^{+}$content in shoot and $\mathrm{Ca}^{2+}$ content in seed of broad bean. The ANOVA of different antioxidant enzymes of broad bean plants was shown in Supplementary Table 4. The S and BA significantly affect the MDA, SOD, CAT, POD and APX activity in broad bean. However, the interaction of $S$ and BA showed significant differences for MDA, SOD, CAT and APX activity except for POD in broad bean plants.

\section{Exogenous BA boosted broad bean growth under salinity stress}

The 'S1' plants showed a considerable reduction in RFW (by 16.17\%), SFW (by 7.16\%), and RDW (by 29.47\%) compared with that of 'C' plants (Figure 1A, B, D), but did show any effect on FSW, SDW, SDW and no. of nodules (Figure 1C, E-G). Moreover, 'S2' plants displayed a marked decrease in RFW (by 48.70\%), RDW (by 70.42\%), SFW (by 59.72\%), SDW (by 42.14\%), FSW (by 45.54\%), DSW (by $53.36 \%$ ) and no. of nodules (by $47.20 \%$ ) compared with 'C' plants (Figure 1A-G). Foliar application of BA to 'B+S1' broad bean assuaged the adverse effects of saline toxicity by significantly improving the RFW, RDW, SFW, SDW, FSW, and no. of nodules (by 31.95\%, 92.54\%, 29.13\%, 25.52\%, 6.37\%, and 31.29\%, respectively), except DSW compared to 'S1' plants (Figure 1A-G). Moreover, 'B+S2' plants also exhibited significant enhancement in SFW, SDW, FSW, DSW and no. of nodules by $91.32,36.21,33.08,55.45$, and $84.73 \%$, respectively, without RDW compared with the 'S2' plants (Figure 1A-G). Moreover, 'BA' plants showed amelioration in all studied growth parameters, versus 'C' plants (Figure 1A).

\section{Exogenous BA enhanced level of osmoprotectants under salinity stress}

The 'S2' plants showed decreased content of SS in the root, shoot and seed (by $55.41 \%, 33.43 \%$ and $36.85 \%$, respectively), and the 'S1' plants also exhibited reduction (Figure 2A-C). However, in contrast with 'S2' plants, 'B+S2' plants exhibited an improved level of SS in the root, shoot and seed (by 43.69\%, 29.15\% and $55.06 \%$, respectively) (Figure 2A-C). Moreover, 'B+S1' plants showed enhanced content SS in the root, shoot and seed compared with 'S1' plants (Figure 2A-C). Furthermore, 'BA' plants induced improvement of SS content in all studied organs, versus 'C' plants (Figure 2A-C). The 'S2' plants displayed a reduced level of SP in the root (by 28.03\%), and seed (by 48.19\%), whereas increased in the shoot (by 27.56\%) in comparison with 'C' plants (Figure 2D-F). Moreover, 'S1' plants recorded an enhanced level of SP in the shoot (by $12.00 \%$ ), whereas decreased in the shoot (by 34.14\%) compared with 'C' plants (Figure 2E, F). However, 'B+S2' plants displayed an increased level of SS in the root, shoot and seed (by $48.42 \%, 34.15 \%$ and $62.02 \%$, respectively) compared to 'S2' plants (Figure 2D-F). Moreover, 'B+S1' plants showed enhanced content SS in the root, shoot and seed compared with 'S1' plants (Figure 2D-F). Furthermore, 'BA' plants displayed an enhanced level of SP in all tested organs, against ' $C$ ' plants (Figure 2D-F). The 'S2' plants exhibited an increased content of FAA in the root, shoot and seed (by $44.12 \%, 46.15 \%$ and $27.70 \%$, respectively), and the 'S1' plants also exhibited similar trends (Figure 2G-I). 

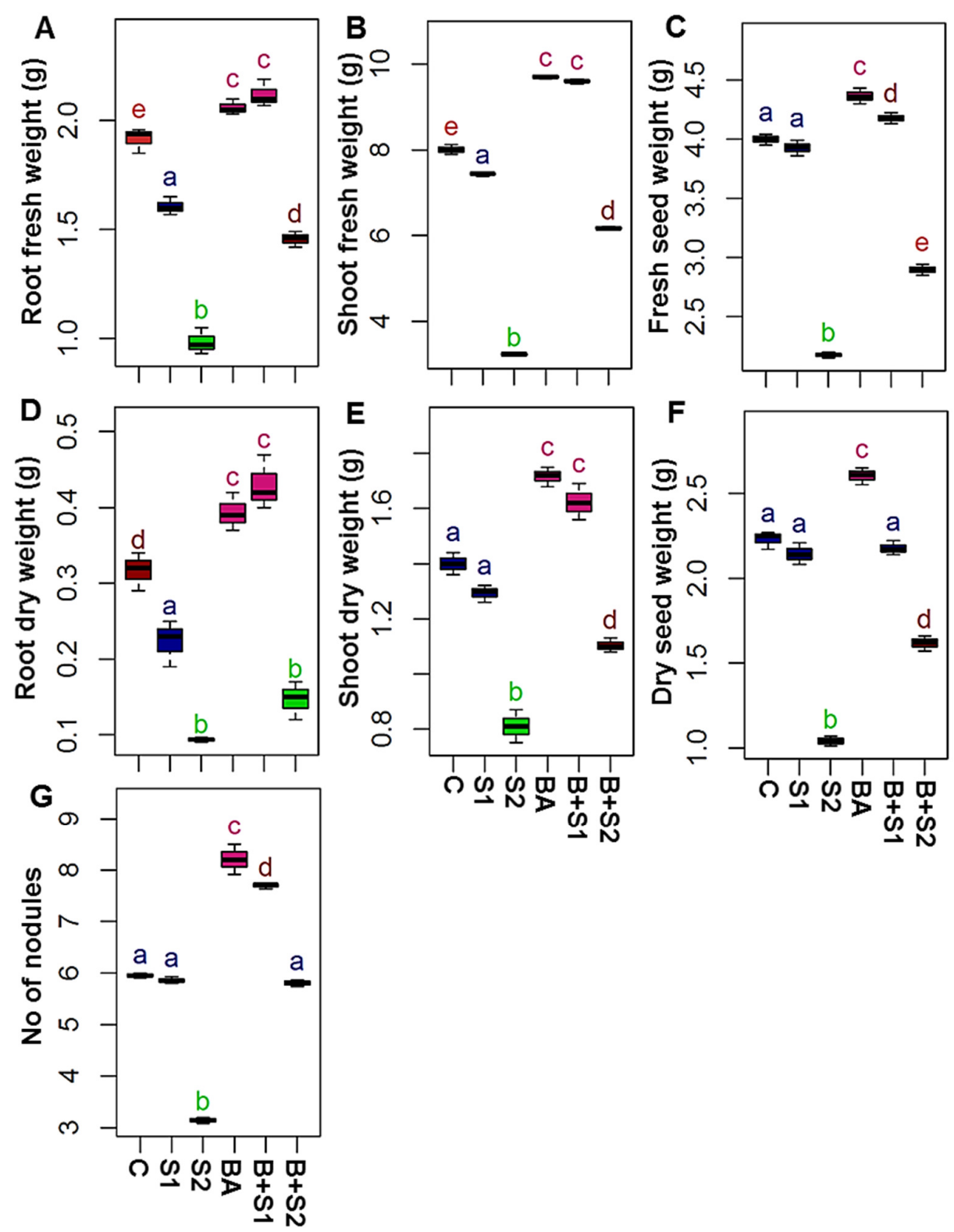

Figure 1. Different growth and yield-related parameters, (A) root fresh weight, (B) shoot fresh weight, (C) fresh seed weight, (D) root dry weight, (E) shoot dry weight, (F) dry seed weight and (G) no. of nodules of broad bean plants exposed to salinity with or without 6-benzyladenine (BA) foliar spray For each treatment, values were obtained from three independent replicates $(n=3)$. Different letters above the bars indicate a statistically significant difference based on $P<0.05$ by Tukey's test. ' $\mathrm{C}$ ', $0 \mathrm{mM} \mathrm{NaCl}+$ distilled water spray (control); 'BA', $0 \mathrm{mM} \mathrm{NaCl}+200$ ppm BA spray; 'S1', $60 \mathrm{mM} \mathrm{NaCl}+$ distilled water spray; 'S2', $150 \mathrm{mM} \mathrm{NaCl}+$ distilled water spray; 'S1+B1', $60 \mathrm{mM} \mathrm{NaCl}+200$ ppm BA spray; and 'B+S2', $150 \mathrm{mM} \mathrm{NaCl}+200$ ppm BA spray. 

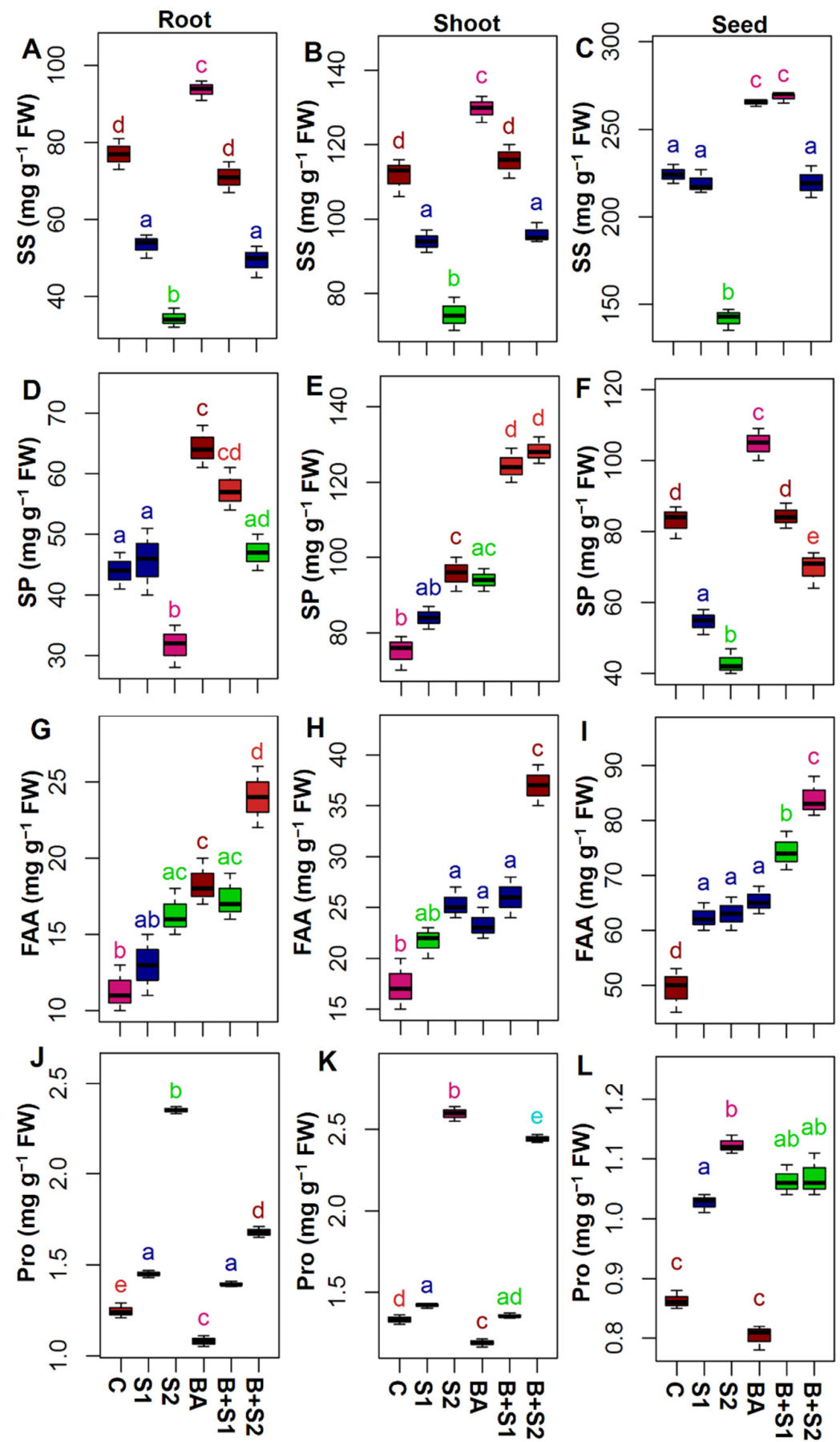

Figure 2. Effect of foliar application of 6-benzyladenine (BA) soluble sugars (SS) content in (A) root (B) shoot and (C) seed; soluble proteins (SP) content in (D) root (E) shoot (F) and seed; free amino acids (FAA) content in $(\mathrm{G})$ root, $(\mathrm{H})$ shoot and $(\mathrm{I})$ seed; proline (Pro) content in $(\mathrm{J})$ root, $(\mathrm{K})$ shoot and $(\mathrm{L})$ seed in broad bean

For each treatment, values were obtained from three independent replicates $(n=3)$. Different letters above the bars indicate a statistically significant difference based on $P<0.05$ by Tukey's test. ' $\mathrm{C}$ ', $0 \mathrm{mM} \mathrm{NaCl}+$ distilled water spray (control); 'BA', $0 \mathrm{mM} \mathrm{NaCl}+200$ ppm BA spray; 'S1', $60 \mathrm{mM} \mathrm{NaCl}+$ distilled water spray; 'S2', $150 \mathrm{mM} \mathrm{NaCl}+$ distilled water spray; 'S1+B1', $60 \mathrm{mM} \mathrm{NaCl}+200 \mathrm{ppm} \mathrm{BA}$ spray; and 'B+S2', $150 \mathrm{mM} \mathrm{NaCl}+200 \mathrm{ppm} \mathrm{BA}$ spray. 
However, in comparison with 'S2' plants, 'B+S2' plants exhibited a further enhanced level of SS in the root, shoot and seed (by 46.94\%, 46.05\% and 33.33\%, respectively) (Figure 2G-I). Moreover, 'B+S1' plants displayed similar trends (Figure 2G-I). Furthermore, 'BA' plants displayed improvement of SS content in all studied parts, compared to 'C' plants (Figure 2G-I). The 'S2' plants displayed increased content of Pro in the root (by 88.50\%), and shoot (by 95.24\%) and seed (by 30.12\%) compared with 'C' plants (Figure 2J-L). Moreover, 'S1' plants also showed an increased level of Pro in the root, shoot and seed (by $12.00 \%$ ), compared with 'C' plants (Figure 2J-L). In contrast, 'B+S2' plants exhibited diminished content of SS in the root, shoot and seed (by $34.15 \%$ and $5.91 \%$ and $4.75 \%$, respectively), in comparison with 'S2' plants (Figure 2J-L). Moreover, 'B+S1' plants showed a reduced level of Pro in shoot and seed compared with 'S1' plants (Figure 2K, L). Furthermore, 'BA' plants displayed a decreased level of SP in root and shoot, versus 'C' plants (Figure 2J, $\mathrm{K})$.

\section{Exogenous BA regulated mineral homeostasis under salt stress}

The 'S2' plants displayed increased content of $\mathrm{Na}^{+}$in the root, shoot and seed (by $509.13 \%, 336.58 \%$ and $440.46 \%$, respectively) in comparison with 'C' plants. Moreover, 'S1' plants showed similar results (Figure $3 \mathrm{~A}-\mathrm{C}$ ). However, in 'B+S2' plant, the amount of $\mathrm{Na}^{+}$was reduced in the root, shoot and seed (by $39.89 \%$, $22.78 \%$ and $33.58 \%$, respectively), relative to the content in S2' plants (Figure 3A-C). Moreover, in 'B+S1' plant, the level of $\mathrm{Na}^{+}$was also reduced in the root, shoot and seed, relative to the content in S1' plants (Figure 3A-C). Furthermore, 'BA' plants displayed decreased content of SP in seed compared to 'C' plants (Figure 3C). The 'S2' plants displayed decreased content of $\mathrm{K}^{+}$in shoot and seed (by $32.39 \%$ and $37.36 \%$, respectively) whereas increased in the root (by 13\%) compared with ' $\mathrm{C}$ ' plants (Figure 3D-F). Moreover, the 'S1' plants showed decreased content of $\mathrm{K}^{+}$in shoot whereas increased in root compared with 'C' plants (Figure 3D, E). However, in ' $\mathrm{B}+\mathrm{S} 2$ ' plant, the amount of $\mathrm{K}^{+}$was amplified in the root, shoot and seed (by $11.10 \%, 42.48 \%$ and $116.53 \%$, respectively), relative to the content in 'S2' plants (Figure 3D-F). Moreover, in 'B+S1' plant, the level of $\mathrm{K}^{+}$was also augmented in roots, shoot and seed, in comparison with 'S1' plants (Figure 3D-F). Furthermore, 'BA' plants enhanced the content of $\mathrm{K}^{+}$in all tested organs compared to ' $\mathrm{C}$ ' plants (Figure 3D-F). The 'S2' plants displayed decreased content of $\mathrm{Ca}^{2+}$ (by $74.44 \%, 59.58 \%$ and $41.67 \%$, respectively) and $\mathrm{Mg}^{2+}$ (by $37.88 \%$, $29.22 \%$ and $33.71 \%$, respectively) in the root, shoot and seed compared with ' $\mathrm{C}$ ' plants and 'S1' plants follow similar trends (Figure 3G-L). However, in 'B+S2' plant, the content of $\mathrm{Ca}^{2+}$ (by $154.70 \%, 46.49 \%$ and $52.38 \%$, respectively), and $\mathrm{Mg}^{2+}$ were amplified in the root, shoot and seed (by $57.89 \%, 43.31 \%$ and $59.44 \%$, respectively), relative to the content in 'S2' plants (Figure 3G-L). Moreover, in 'B+S1' plant, the level of $\mathrm{Ca}^{2+}$ and $\mathrm{Mg}^{2+}$ was also augmented in the root, shoot and seed, in comparison with 'S1' plants (Figure 3G-L). Furthermore, 'BA' plants enhanced the content of $\mathrm{Ca}^{2+}$ and $\mathrm{Mg}^{2+}$ in all examined organs compared to ' $\mathrm{C}$ ' plants (Figure 3G-L).

We estimated the mineral translocation rates within different parts of broad bean, i.e. root to shoot, shoot to seed, and root to seed. ' $\mathrm{S} 2$ ' plants showed decreased translocations for $\mathrm{Na}^{+}$from root to shoot and root to seed whereas increased from shoot to seed compared with 'C' plants (Figure 4A-C). Moreover, 'S1' plants showed increased translocations for $\mathrm{Na}^{+}$from shoot to seed and root to seed compared with 'C' plants (Figure $4 \mathrm{~A}-\mathrm{C})$. However, ' $\mathrm{B}+\mathrm{S} 2$ ' plants showed improved translocations for $\mathrm{Na}^{+}$from root to shoot and root to seed whereas declined from shoot to seed compared with 'S2' plants (Figure 4A-C).

Moreover, 'S1' plants showed decreased translocations for $\mathrm{Na}^{+}$from shoot to seed and root to seed compared with 'S1' plants (Figure 4B, C). 'BA' plants showed decreased translocations for $\mathrm{Na}^{+}$from shoot seed and root to seed compared with 'C' plants (Figure 4B, C). 'S2' plants showed decreased translocations for $\mathrm{K}^{+}$ from all different parts compared with 'C' plants (Figure 4D-F). Moreover, 'S1' plants showed reduced translocations for $\mathrm{K}^{+}$from root to shoot and root to seed compared with 'C' plants (Figure 4D-F). 

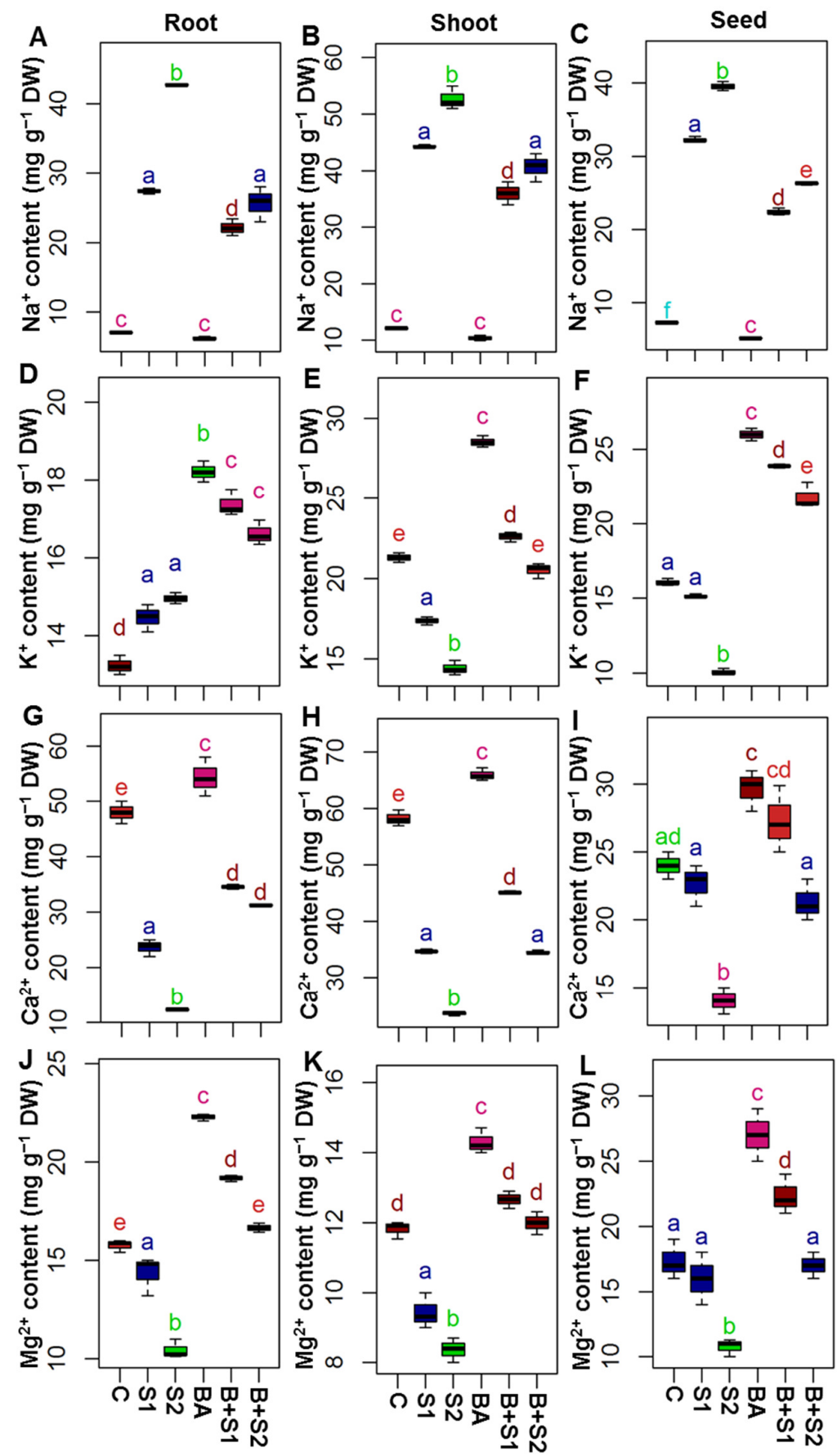

Figure 3. Nutrient contents in different parts of broad bean plants exposed to salt stress with or without 6-benzyladenine (BA) treatment. $\mathrm{Na}^{+}$content in (A) root (B) shoot and (C) seed; $\mathrm{K}^{+}$content in (D) root (E) shoot and (F) seed; $\mathrm{Ca}^{2+}$ content in $(\mathrm{G})$ root, $(\mathrm{H})$ shoot and (I) seed; and $\mathrm{Mg}^{2+}$ content in $(\mathrm{J})$ root, $(\mathrm{K})$ shoot and $(\mathrm{L})$ seed in broad bean plants

For each treatment, values were obtained from three independent replicates $(n=3)$. Different letters above the bars indicate a statistically significant difference based on $P<0.05$ by Tukey's test. ' $\mathrm{C}$ ', $0 \mathrm{mM} \mathrm{NaCl}+$ distilled water spray (control); 'BA', $0 \mathrm{mM} \mathrm{NaCl}+200$ ppm BA spray; 'S1', $60 \mathrm{mM} \mathrm{NaCl}+$ distilled water spray; ' $\mathrm{S} 2$ ', $150 \mathrm{mM} \mathrm{NaCl}+$ distilled water spray; 'S1+B1', $60 \mathrm{mM} \mathrm{NaCl}+200$ ppm BA spray; and 'B+S2', $150 \mathrm{mM} \mathrm{NaCl}+200 \mathrm{ppm} \mathrm{BA}$ spray. 

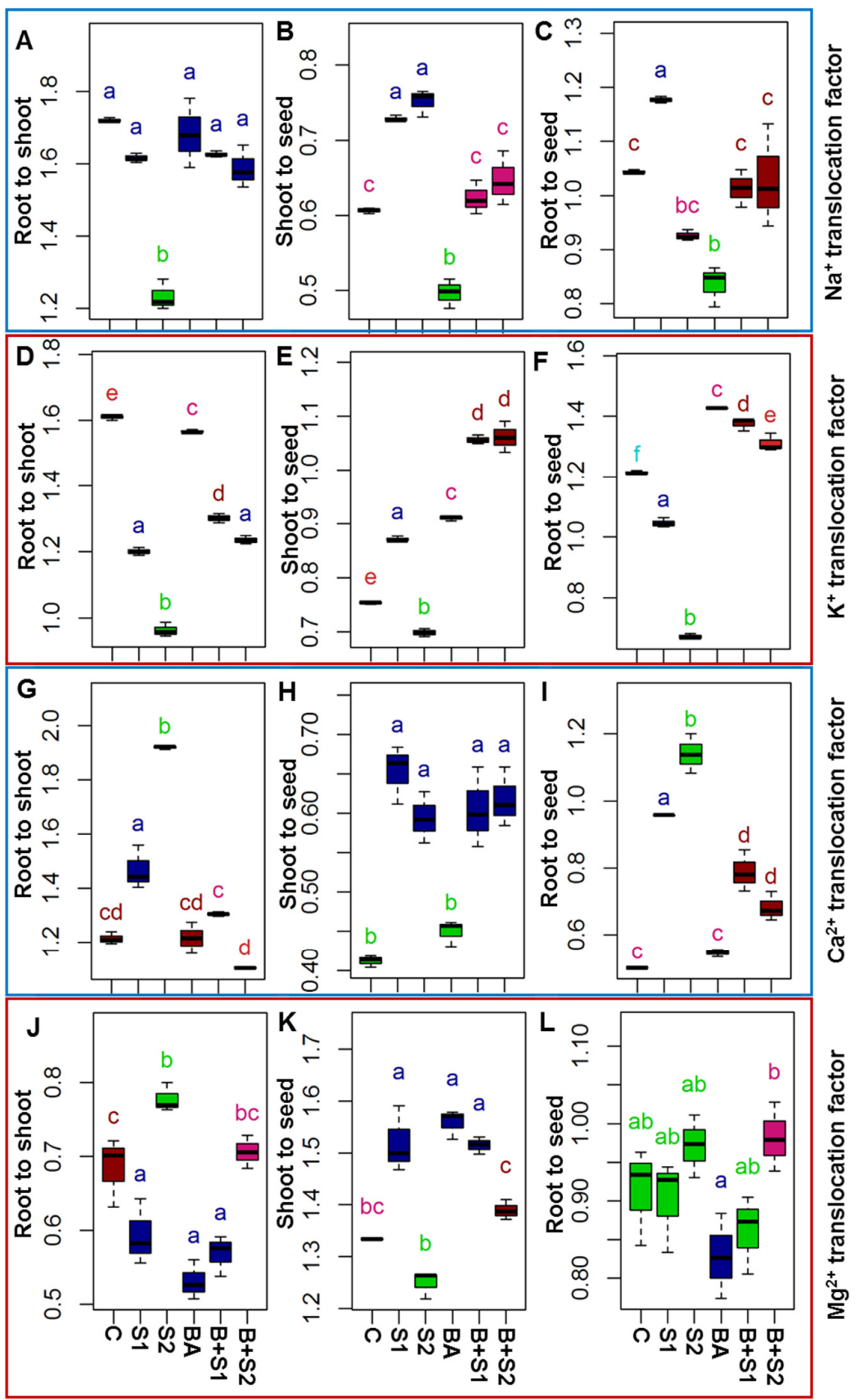

Figure 4. Translocation of nutrients in different parts of broad beans exposed to salt stress with or without 6-benzyladenine (BA) treatment. Translocation factor of $\mathrm{Na}^{+}$in (A) root to shoot (B) shoot to seed (C) root to seed; $\mathrm{K}^{+}$in $(\mathrm{D})$ root to shoot $(\mathrm{E})$ shoot to seed $(\mathrm{F})$ root to seed; $\mathrm{Ca}^{2+}$ in $(\mathrm{G})$ root to shoot $(\mathrm{H})$ shoot to seed (I) root to seed; and $\mathrm{Mg}^{2+}$ in $(\mathrm{J})$ root to shoot $(\mathrm{K})$ shoot to seed $(\mathrm{L})$ root to seed in broad bean plants For each treatment, values were obtained from three independent replicates $(n=3)$. Different letters above the bars indicate a statistically significant difference based on $P<0.05$ by Tukey's test. 'C', $0 \mathrm{mM} \mathrm{NaCl}+$ distilled water spray (control); 'BA', $0 \mathrm{mM} \mathrm{NaCl}+200$ ppm BA spray; 'S1', $60 \mathrm{mM} \mathrm{NaCl}+$ distilled water spray; 'S2', $150 \mathrm{mM} \mathrm{NaCl}+$ distilled water spray; ' $\mathrm{S} 1+\mathrm{B1}$ ', $60 \mathrm{mM} \mathrm{NaCl}+200 \mathrm{ppm} \mathrm{BA}$ spray; and 'B+S2', $150 \mathrm{mM} \mathrm{NaCl}+200 \mathrm{ppm} \mathrm{BA}$ spray. 
However, ' $\mathrm{B}+\mathrm{S} 2$ ', ' $\mathrm{B}+\mathrm{S} 1$ ' and 'BA' plants showed improved translocations for $\mathrm{K}^{+}$in all parts of broad bean compared with 'S2', 'S1' and 'C' plants, respectively (Figure 4D-F). 'S2' and 'S1' plants showed increased translocations for $\mathrm{Ca}^{2+}$ in all studied organs compared with 'C' plants (Figure 4G-I). However, 'B+S2' and ' $\mathrm{B}+\mathrm{S} 1$ ' plants showed decreased translocations for $\mathrm{Ca}^{2+}$ from root to shoot and root to seed compared with ' $\mathrm{S2}$ ' and 'S1' plants, respectively (Figure 4G, I). 'S2' plants showed decreased translocations for $\mathrm{Mg}^{2+}$ from root to shoot to seed whereas increased from shoot to seed compared with 'C' plants (Figure 4J, K). Moreover, 'S1' plants reverse this trend (Figure 4J, K). However, 'B+S2' plants showed declined translocations for $\mathrm{Mg}^{2+}$ from root to shoot whereas increased from shoot to seed compared with 'S2' plants (Figure 4J, K)

Exogenous BA reduced MDA content and improved antioxidant defence system under salt stress

The production of MDA was markedly increased by $7.92 \%$ and $99.32 \%$ at both $S 1$ and $S 2$ treatment compared with 'C' plants (Figure 5A). Supplementation of BA to both 'S1' and 'S2' plants showed significant abatement in MDA content by $19.90 \%$ and $46.49 \%$ in comparison with 'S1' and 'S2' salt-stressed plants, respectively (Figure 5A).
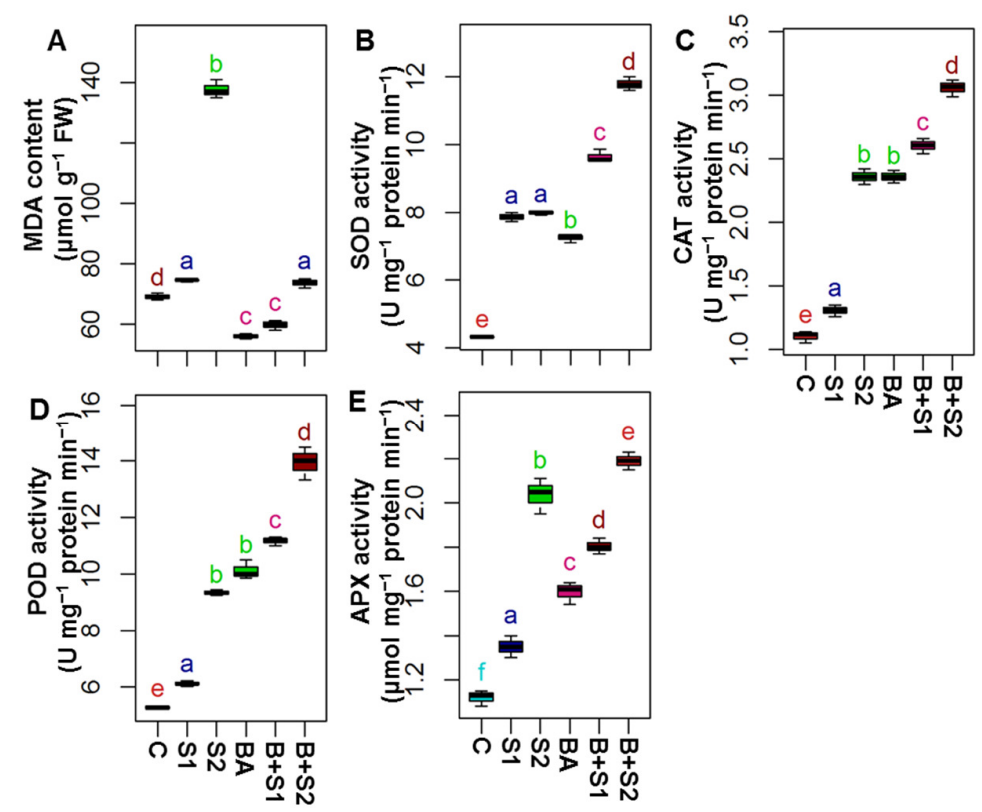

Figure 5. Levels of (A) malondialdehyde (MDA) content (B) SOD (superoxide dismutase) activity, (C) CAT (catalase) activity, (D) POD (peroxidase) activity, and (E) APX (ascorbate peroxidase) activity in broad bean plants exposed to salinity with or without 6-benzyladenine (BA) foliar spray

For each treatment, values were obtained from three independent replicates $(n=3)$. Different letters above the bars indicate a statistically significant difference based on $P<0.05$ by Tukey's test. 'C', $0 \mathrm{mM} \mathrm{NaCl}+$ distilled water spray (control); 'BA', $0 \mathrm{mM} \mathrm{NaCl}+200$ ppm BA spray; 'S1', $60 \mathrm{mM} \mathrm{NaCl}+$ distilled water spray; 'S2', $150 \mathrm{mM} \mathrm{NaCl}+$ distilled water spray; 'S1+B1', $60 \mathrm{mM} \mathrm{NaCl}+200$ ppm BA spray; and 'B+S2', $150 \mathrm{mM} \mathrm{NaCl}+200 \mathrm{ppm} \mathrm{BA}$ spray.

Furthermore, 'BA' plants also showed a significant reduction in MDA content (Figure 5A). The activities of SOD, CAT, POD, and APX were significantly increased (by 85.02\%, 113.90\%, 77.23\%, and $81.85 \%$, respectively) in 'S2' plants compared with 'C' plants (Figure 5B-E). Moreover, 'S1' plants followed a similar trend in all studied antioxidant enzymes (Figure 5B-E). However, 'B+S1' plants showed significant improvement in the activity of SOD, CAT, POD, and APX by $22.59 \%, 99.23 \%, 82.42 \%$, and $33.58 \%$, respectively, in comparison to 'S1' plants (Figure 5B-E). Likewise, 'B+S2' plants markedly improved the activities of SOD, CAT, POD, and APX by 47.62\%, 29.66\%, 49.29\% and 7.53\%, respectively, in comparison 
with the 'S2' plants (Figure 5B-E). Furthermore, enhanced activities of all examined antioxidant enzymes were recorded in 'BA' plants compared with 'C' plants (Figure 5B-E).

\section{Hierarchical clustering and PCA analysis}

The morpho-physiological, biochemical, and growth attributing data under both control and salinity stress conditions were subjected to hierarchical clustering, heatmap analysis, and PCA (Figure 6).
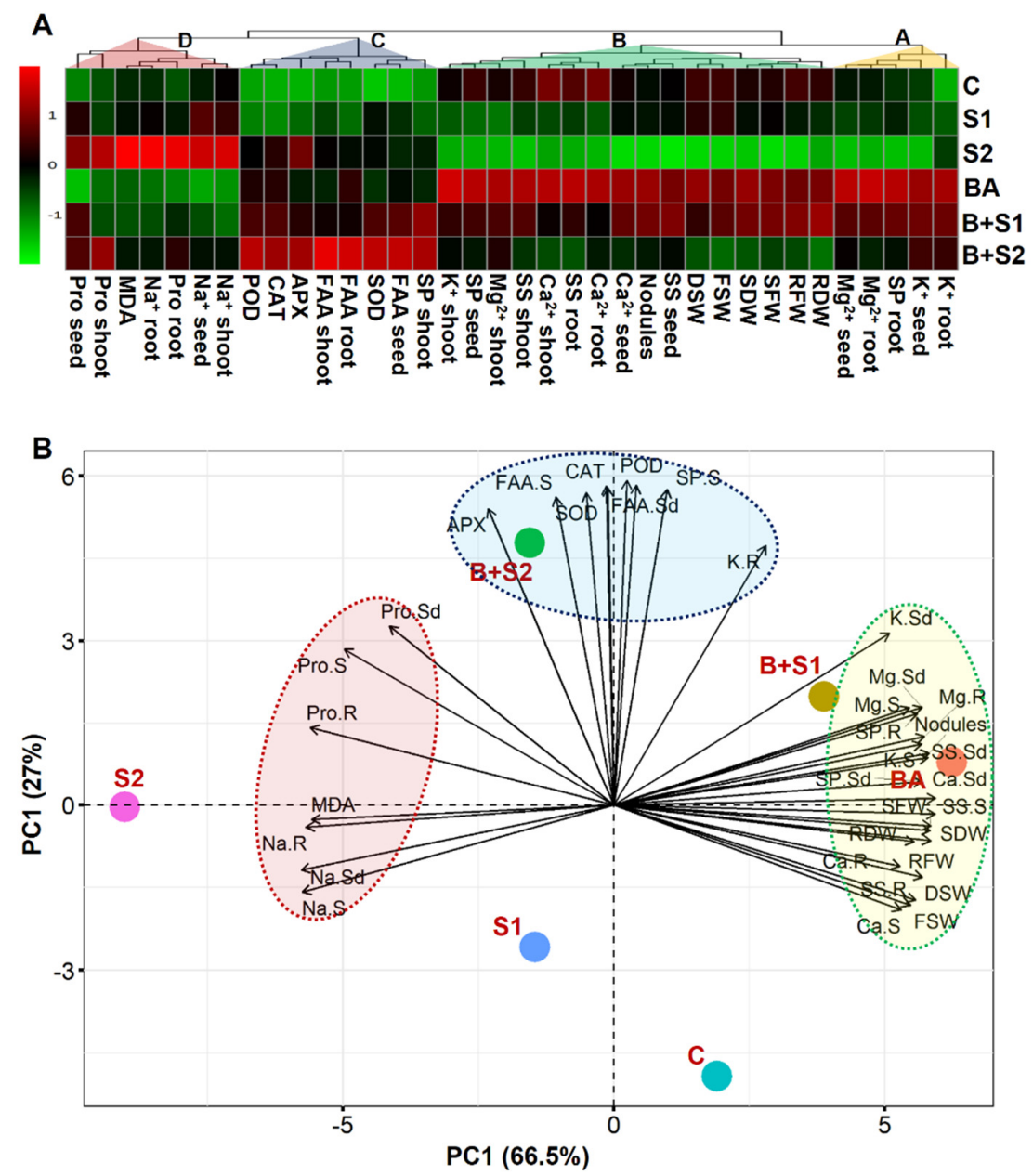

Figure 6. Hierarchical clustering and heatmap (A) to elucidate the treatment variable relationships. The mean values of the various parameters obtained in this study were normalized and clustered. The entire dataset was analysed using principal component analysis (PCA) (B)

The variables included shoot fresh weight (SFW), fresh seed weight (FSW), root dry weight (RDW), shoot dry weight (SDW), dry seed weight (DSW), no. of nodules, soluble sugars (SS), soluble proteins (SP), free amino acids (FAA), proline (Pro), malondialdehyde content (MDA), superoxide dismutase (SOD) activity, catalase (CAT) activity, peroxidase (POD) activity, ascorbate peroxidase (APX) activity. 'C', $0 \mathrm{mM} \mathrm{NaCl}+$ distilled water spray (control); 'BA', $0 \mathrm{mM} \mathrm{NaCl}+200$ ppm BA spray; 'S1', $60 \mathrm{mM} \mathrm{NaCl}+$ distilled water spray; 'S2', $150 \mathrm{mM} \mathrm{NaCl}+$ distilled water spray; 'S1+B1', $60 \mathrm{mM} \mathrm{NaCl}+200$ ppm BA spray; and 'B+S2', $150 \mathrm{mM} \mathrm{NaCl}+200$ ppm BA spray.

According to Hierarchical clustering results, these parameters were classified into four clusters (clusterA-D) (Figure 6A). $\mathrm{K}^{+}$root, $\mathrm{K}^{+}$seed, SP root, $\mathrm{Mg}^{2+}$ root and $\mathrm{Mg}^{2+}$ seed were clustered into cluster-A. and RDW, RFW, SFW, SDW, FSW, DSW, SS seed, no. of nodules, $\mathrm{Ca}^{2+}$ seed, $\mathrm{Ca}^{2+}$ root, $\mathrm{SS}$ root, $\mathrm{Ca}^{2+}$ shoot, $\mathrm{SS}$ shoot, $\mathrm{Mg}^{2+}$, SP seed, $\mathrm{K}^{+}$shoot were included in cluster-B. In comparison with ' $\mathrm{C}$ ', all cluster-A and cluster-B 
included parameter showed a negative affinity in ('S1' and 'S2') broad bean under salt stress, whereas a positive affinity was noticed in BA-treated salt-stressed (' $\mathrm{B}+\mathrm{S} 1$ ' and ' $\mathrm{B}+\mathrm{S} 2$ ') broad bean in comparison with saltstressed plants (Figure 6A). It has been observed that BA treated stress-free broad bean which showed the highest level of increment of these parameters were grouped into cluster-A and cluster-B. However, cluster- $\mathrm{C}$ was comprised of SP shoot, FAA seed, SOD, FAA root, FAA shoot, APX, CAT and POD (Figure 6A). In comparison with ' $\mathrm{C}$ ', every parameter of cluster- $\mathrm{C}$ exhibited an increasing trend in both salt-stressed ('S1' and 'S2') and BA-treated salt-stressed ('B+S1' and 'B+S2') broad bean plants (Figure 6A). Moreover, B+S2 treated stressed broad bean plants that exhibited the highest level of increment of these parameters were grouped into cluster-C. Cluster D was classified as $\mathrm{Na}^{+}$shoot, $\mathrm{Na}^{+}$seed, Pro root, $\mathrm{Na}^{+}$root, MDA, Pro shoot, Pro seed. On the contrary to other clusters, every parameter of cluster-D showed an increasing trend in salt-affected plants ('S1' and 'S2') in comparison with control (Figure 6A). But the fall of these parameters was observed when the stressed plants are treated with $\mathrm{BA}\left({ }^{\prime} \mathrm{B}+\mathrm{S} 1\right.$ ' and ' $\mathrm{B}+\mathrm{S} 2$ ') broad bean plants. 'S2' plants evidenced that the highest level of increment was observed in those parameters which grouped into cluster-D (Figure 6A).

We accomplished PCA for determining acquaintance between the treatment groups and the morphophysiological and biochemical parameters. The PCA biplotelicits segregation clearly among the groups of six treatments ('C', 'S1', 'S2', 'B+S1', 'B+S2' and 'BA') (Figure 6B). Both the first and second components of PCA elucidate approximately $93.5 \%$ data variability (Figure 6B). Experimental results showed that heatmap cluster$\mathrm{A}$ and $-\mathrm{B}$ variables (Figure $6 \mathrm{~A}$ ) were moderately associated with ' $\mathrm{C}$ ' and strongly associated with 'B+S1' treatments (Figure 6B), whereas the heatmap cluster-C variables (Figure 6A) were intensely interlinked to ' $\mathrm{B}+\mathrm{S} 2$ ' treatments (Figure 6B). The variables of heatmap cluster-B (Figure 6A) were sharply interlinked with 'S2' and moderately interlinked with 'S1' treatment (Figure 6B).

\section{Discussion}

Various small organic compounds, such as plant growth regulators and signal molecules, could be applied as a powerful tool in improving and enhancing plants' adaptability against several unfavourable environments such as soil salinity (Fahad et al., 2015; Mostofa et al., 2015; Ahmed et al., 2019). Application of exogenous phytohormones including $\mathrm{CK}$ has been proven as a promising sight in the alleviation of the adverse effects of salt toxicity in several vegetables and crops, such as brinjal (Solanum melongena Mill.), soybean (Glycine max L.), mung bean (Cucumis sativus L.), rice (Oryza sativa L.) and maize (Zea mays L.) (Hadiarto and Tran, 2011; Javid et al., 2011a; Wu et al., 2014; Fahad et al., 2015; Tahjib-Ul-Arif et al., 2018b; Akram et al., 2019; Rahman et al., 2019). An important synthetic CK, BA has been recognized as the potential stress-mitigating phytohormones to the scientific community. The purpose of our current investigation is to explore the potential role of BA in enhancing salinity tolerance in broad bean plants.

In plants, salinity from soil or irrigation initially creates an imbalance in ionic homeostasis, which consequently provokes osmotic impairments and oxidative damages, both of which noticeably limit the growth and development of plants (Jiang et al., 2019). The negative effects of the abiotic factor on vegetable-producing plants can be appraised by determining the physiological and morphological attributes (Akram et al., 2019). The current experiment revealed that salinity elicited its obvious adverse effects on broad bean growth and biomass production, whereas the exogenous application of BA assuaged the salt-induced injurious impacts (Figure 1). To understand the underlying defense mechanisms of BA-mediated salt acclimation, we investigated various physio-biochemical characters (Figures 2-5). The RFW, SFW, FSW, RDW, SDW, DSW and no. of nodules of the salt-stressed broad bean were reduced as compared to control (Figure 1), which endured by an imbalance of mineral homeostasis and oxidative injury in plants (Figures 3,5). However, foliar application of BA recovered salt-affected damage by improving the phenotypic characteristics and plant growth features which includes RFW, SFW, FSW, RDW, SDW, DSW and no. of nodules (Figure 1), perhaps by balancing mineral homeostasis (Figure 3), and maintaining ROS production and lipid peroxidation (Figure 5). 
In concord with our findings, it was mentioned that exogenous BA enhanced plant growth of brinjal (Wu et al., 2014), maize (Ren et al., 2017; Hu et al., 2020) and wheat under salt-stress and waterlogging conditions (Iqbal et al., 2006). Furthermore, our works were supported by PCA, which implied that BA treated salt injured plant of broad bean showed a stronger correlation with plant growth features as compared with ' $\mathrm{S1}$ ' and 'S2' plants (Figure 6B), exhibiting an influential application of BA in the mitigation of the salt adverse effect on the plant growth-related features and physiology.

An important osmoprotectant, Pro was widely used as an efficient marker in plant salt tolerance mechanism because of its crucial role in the osmotic adjustment of plants (Sharma et al., 2011; Uddin et al., 2012). Besides, under abiotic stress conditions, osmoregulants lay an important role in the sustainable growth and development of plants (Zulfiqar et al., 2020). Thus, the plant maintains its water balance and osmotic potential by accumulating essential osmolytes like Pro, SS, SP and FAA (Mansour and Ali, 2017; Hasanuzzaman et al., 2019). Our result revealed that proline was rapidly accumulated by salt-exposed broad bean and subsequent increment of SP and FAA content except for SS to regulated the metabolic activity by maintaining osmotic homeostasis (Figure 2). Our findings is similar to the results obtained from the response dos salt stressed cucumber (Cucumis sativus L.) (Fan et al., 2012), Salvadora persica (Parida et al., 2016), maize (Fu et al., 2017) and rice (Wang et al., 2018), drought-stressed barley (Hordeum vulgare L.) (Bandurska et al., 2017; Dbira et al., 2018) and cold-stressed rice (Sohag et al., 2020b). However, the exogenous supply of BA significantly reduced the excess Pro produced under salt stress and improved plant growth (Figures 1, 2J-L). Intriguingly, increased levels of SS, SP, FAA in ' $\mathrm{B}+\mathrm{S} 1$ ' and ' $\mathrm{B}+\mathrm{S} 2$ ' plants revealed that exogenous BA strongly compensated Pro by absorbing those osmoprotectants to ensure osmotic adjustments (Figure 2). A parallel result was reported in eggplant, wheat and rapeseed (Brassica napus L.) plants (Wu et al., 2014; Nawaz et al., 2015; Khan et al., 2019a, 2019b).

Our study indicated that excess salt accumulation in broad bean destroyed the balance of mineral homeostasis and thus the plant growth was retired. Salt stress decreased $\mathrm{K}^{+}, \mathrm{Ca}^{2+}$ and $\mathrm{Mg}^{2+}$ contents in all parts (except $\mathrm{K}^{+}$content in root) (Figure 3D-L), which because of excess accumulation of $\mathrm{Na}^{+}$in shoot and other organs (Figure 3A-C). With the increased absorption rate of $\mathrm{Na}^{+}$and $\mathrm{Cl}^{-}$ions, a significant decline in other ions (e.g., $\mathrm{K}^{+}, \mathrm{Ca}^{2+}$, and $\mathrm{Mg}^{2+}$ ) exhibited in many experiments (Hakim et al., 2014; Orlovsky et al., 2016; Mahmud et al., 2017). Exogenous plant hormone (e.g. CK) application on salt-stressed rice and rapeseed plants was found to alleviate the salt antagonistic effects on the morpho-physiological and biochemical characteristics of these crops (Anuradha and Rao, 2001; Khan et al., 2019b). However, exogenous BA application reestablished ionic balance by mitigating uptake of excessive $\mathrm{Na}^{+}$and enhancing the $\mathrm{K}^{+}, \mathrm{Ca}^{2+}$ and $\mathrm{Mg}^{2+}$ level in broad bean which may ensure proper nourishment and normal plant growth (Figures 1,3). Our present results are strongly correlated $\mathrm{K}^{+}, \mathrm{Ca}^{2+}$ and $\mathrm{Mg}^{2+}$ contents with 'B+S1' and 'B+S2' plants than 'S1' and 'S2' plants which was clearly and powerfully supported by PCA analysis (Figure 6B). A similar result was noticed in several experiments that were undertaken in different environmental stress conditions (Gurmani et al., 2007; Ding et al., 2017; Yan et al., 2018; Sohag et al., 2020a). Moreover, control, 'B+S1' and 'B+S2' plants accumulated higher concentrations of $\mathrm{Ca}^{2+}$ and $\mathrm{Mg}^{2+}$ (Figure 3G-L). It suggested that exogenous $\mathrm{BA}$ enhanced plant growth by up-regulating the uptake capacity of divalent cations in broad bean. Enhanced content of $\mathrm{Ca}^{2+}$ and $\mathrm{Mg}^{2+}$ plays a crucial role in the proper functioning of some biological processes such as protein synthesis, enzymatic stimulation, signal transduction and fortification of cell membrane structure fortification (Chen et al., 2010; Guo, 2017). The abundance of nutrients especially $\mathrm{K}^{+}$to plants enhances the plant's ability to survive under stressed conditions (Shrivastava and Kumar, 2015).

Our study also revealed that nutrient $\left(\mathrm{Na}^{+}, \mathrm{K}^{+}, \mathrm{Ca}^{2+}\right.$ and $\left.\mathrm{Mg}^{2+}\right)$ translocations from root to shoot, shoot to seed and root to seed were severely attenuated as much of these ions were accumulated in roots of ' $\mathrm{S} 1$ ' and 'S2'plants (Figure 4A-L). Moreover, our findings further revealed that the preferential allocation of minerals in roots contributed to retard plant growth and injury in the aerial portion of broad bean under salt stress (Figures 1A, 4F-J). On the contrary, exogenous supplementation of BA superbly augmented mineral uptake and translocation in ' $\mathrm{B}+\mathrm{S} 1$ ' and ' $\mathrm{B}+\mathrm{S} 2$ ' plants (Figure $4 \mathrm{~F}-\mathrm{J}$ ). BA-induced improvement of plant roots 
branching and growth of root-shoot growth likely facilitated broad bean foraging for excess mineral and water from the neighboring and adjacent rooted layer of soil (Khan et al., 2018; Nadeem et al., 2019).

MDA has been recognized as an excellent marker for measuring the destruction of the membrane due to oxidative stress in plants (Miller et al., 2010). ROS accumulation in response to salt stress is responsible for creating oxidative damage, showed a positive and frequent correlation with the content of MDA in plants, as noticed in soybean, broad bean, wheat and Rosa hybrida (Siddiqui et al., 2017; Soundararajan et al., 2018). The present research revealed that excess salt uptake in broad bean resulted in oxidative damage by overproducing ROS and thus MDA content was significantly increased in leaves, which ultimately promoted huge growth retardation and yield loss of broad bean (Figures 1, 5A). On the contrary, exogenous BA treatment to broad bean leaves alleviated salt-mediated oxidative injury, as strongly supported by the reduced MDA content in the of ' $\mathrm{B}+\mathrm{S} 1$ ' and ' $\mathrm{B}+\mathrm{S} 2$ ' plants leaves (Figure $5 \mathrm{~A}$ ), which was similar to the findings in maize under salinity and submerge conditions and faba bean under salt stress (Shah, 2011; Ren et al., 2018; Tahjib-Ul-Arif et al., 2018b; Ahmad et al., 2019). When the plants are exposed to salt stress, it produces toxic ROS which resulted in oxidative damage and retard the growth of the plant (Tang et al., 2015; Roy et al., 2019). However, the increased activities of some antioxidants showed an efficient and effective remedy against ROS toxicity and oxidative damage (Hanin et al., 2016; Engwa, 2018). In our current investigation, we observed that the enzymatic activity of all antioxidants (namely SOD, CAT, POD and APX) was enhanced in both salt-treated plants (Figure 5B-E). Our result was supported by experiments on soybean (Weisany et al., 2012), maize (Tahjib-Ul-Arif et al., 2018b) and rice (Roy et al., 2019), whereas opposite findings were reported in Pisum sativum (Öztürk, 2012) and rice (Tahjib-Ul-Arif et al., 2018a). However, foliar spraying BA to both stresstreated plant leaves, further accelerated the activities of all studied antioxidant enzymes (Figure 5B-E), suggesting an advanced antioxidant capacity of the broad bean plants in response to ' $\mathrm{B}+\mathrm{S} 1$ ' and ' $\mathrm{B}+\mathrm{S} 2$ ' treatment to detoxify salt-induced ROS. In current experiments, BA stimulated the activities of antioxidant enzyme SOD and POD under salt stress, according to the study in Nigella sativa (Shah, 2011), eggplant (Wu et al., 2014) and maize (Hu et al., 2020). Moreover, BA increased the activities of CAT and APX under salt stress, which results were supported by the findings in eggplant (Wu et al., 2014), strawberry (Faghih et al., 2017) and faba bean (Ahmad et al., 2019). The enhanced activity of SOD was correlated with the salinity tolerance in plants (Ma et al., 2012). Besides, POD, CAT and APX are work as $\mathrm{H}_{2} \mathrm{O}_{2}$ scavenging enzymes in cells (Mittler, 2002; Roy et al., 2019).

Our results indicate that the potential activity of exogenous BA positively energizes the plant growth by providing oxidative protection which might augment plants' entire metabolic process and antioxidant capacity, thereby broad bean plant develop tolerance mechanism against salt-stress (Figures 1,5). The PCA also suggested that ' $\mathrm{B}+\mathrm{S1}$ ' and ' $\mathrm{B}+\mathrm{S} 2$ ' plants had a strong and positive correlation with $\mathrm{SOD}, \mathrm{POD}, \mathrm{CAT}$ and $\mathrm{APX}$ activity than 'S1' and 'S2' plants (Figure 6B).

\section{Conclusions}

It is concluded that salt stress caused severe osmotic damage, created oxidative damage, disrupted the essential mineral homeostatic balance and retarded the normal growth of plants. Our present study describes the first proof of exogenous BA-induced plant stress tolerance mechanisms against salinity in broad bean. The favourable application of exogenous BA might contribute to alleviating salt-induced excess adsorption of ROS by improving antioxidant enzymatic activity of SOD, CAT, POD and APX. Moreover, foliar application of BA might maintain osmotic potentiality and plant metabolic activity by modulating Pro, SP, and SS and FAA levels in the broad bean grown in salt-affected soils, which might assist in enhancing essential water uptake capacity and plant physiological response under salinity stress condition. Moreover, under salt stress regimes BA treatment strongly upregulated the mineral homeostasis by controlling $\mathrm{Na}^{+}, \mathrm{K}^{+}, \mathrm{Ca}^{2+}$ and $\mathrm{Mg}^{2+}$ contents. Finally, the detailed study suggests that exogenous application of BA might be considered as an effective and 
powerful strategy in alleviating the antagonistic activity of salt toxicity, thereby latterly ensured sustainable growth and development of broad bean. Furthermore, the molecular investigation is needed to explore new insights into a better understanding of the extensive biological functions of BA-mediated salt stress response and tolerance mechanism in broad bean.

\section{Authors' Contributions}

Conceptualization: AAHAL; Formal analysis: AAHAL; MTUA; Funding acquisition; AAHAL; Investigation: MH, MTUA; Methodology; AAHAL; Project administration; AAHAL; Resources; AAHAL; Software: MTUA; Supervision; AAHAL; Validation: MH, MTUA; Visualization: MTUA; Writing - original draft: MH; Writing - review and editing: AAHAL, MTUA. All authors read and approved the final manuscript.

\section{Acknowledgements}

The authors would like to extend their sincere appreciation to their Institutions and acknowledge the Taif University Researchers Supporting Project number (TURSP-2020/72), Taif University, Taif, Saudi Arabia.

\section{Conflict of Interests}

The authors declare that there are no conflicts of interest related to this article.

\section{References}

Abdel Latef AA, Abu Alhmad MF, Abdelfattah KE (2017b). The possible roles of priming with $\mathrm{ZnO}$ nanoparticles in mitigation of salinity stress in lupine (Lupinus termis) plants. Journal of Plant Growth Regulation 36:60-70. https://doi.org/10.1007/s00344-016-9618-X

Abdel Latef AA, Abu Alhmad MF, Kordrostami M, Abo-Baker A-B A-E, Zakir A (2020a). Inoculation with Azospirillum lipoferum or Azotobacter chroococcum reinforces maize growth by improving physiological activities under saline conditions. Journal of Plant Growth Regulation 39:1293-1306. https://doi.org/10.1007/s00344-020-10065-9

Abdel Latef AA, Abu Alhmad MFA, Ahmad S (2017a). Foliar application of fresh moringa leaf extract overcomes salt stress in fenugreek (Trigonella foenum-graecum) plants. Egyptian Journal of Botany 57:157-179. https://doi.org/10.21608/ejbo.2017.317.1011

Abdel Latef AA, Dawood MF, Hassanpour H, Rezayian M, Younes NA (2020b). Impact of the static magnetic field on growth, pigments, osmolytes, nitric oxide, hydrogen sulfide phenylalanine ammonia-lyase activity, antioxidant defense system, and yield in lettuce. Biology 9(7):172. https://doi.org/10.3390/biology9070172

Abdel Latef AA, Kordrostami M, Zakir A, Zaki H, Saleh OM (2019a). Eustress with $\mathrm{H}_{2} \mathrm{O}_{2}$ facilitates plant growth by improving tolerance to salt stress in two wheat cultivars. Plants 8:303. https://doi.org/10.3390/plants8090303

Abdel Latef AA, Mostofa MG, Rahman MM, Abdel-Farid IB, Tran L-SP (2019b). Extracts from yeast and carrot roots enhance maize performance under seawater-induced salt stress by altering physio-biochemical characteristics of stressed plants. Journal of Plant Growth Regulation 38:966-979. https://doi.org/10.1007/s00344-018-9906-8

Abdel Latef AA, Omer AM, Badawy AA, Osman MS, Ragaey MM (2021). Strategy of salt tolerance and interactive impact of Azotobacter chroococcum and/or Alcaligenes faecalis inoculation on canola (Brassica napus L.) plants grown in saline soil. Plants 10(1):110. https://doi.org/10.3390/plants 10010110 
Abdel Latef AA, Shaddad MAK, Ismail AM, Abu Alhmad MF (2009). Benzyladenine can alleviate saline injury of two roselle (Hibiscus sabdariffa) cultivars via equilibration of cytosolutes including anthocyanins. International Journal of Agriculture and Biology 11:151-157. https://doi.org/08-326/AWB-MMI/2009/11-2-151-157

Abdel Latef AA, Srivastava AK, Saber H, Alwaleed EA, Tran L-SP (2017c). Sargassum muticum and Jania rubens regulate amino acid metabolism to improve growth and alleviate salinity in chickpea. Scientific Reports 7:10537. https://doi.org/10.1038/s41598-017-07692-W

Abdel Latef AA, Zaid A, Abo-Baker ABE, Salem W, Abu Alhmad MF (2020c). Mitigation of copper stress in maize by inoculation with Paenibacillus polymyxa and Bacillus circulans. Plants 9:1513. https://doi.org/10.3390/plants9111513

Abdel Latef AAH, Srivastava AK, El-sadek MSA, Kordrostami M, Tran LP (2018). Titanium dioxide nanoparticles improve growth and enhance tolerance of broad bean plants under saline soil conditions. Land Degradation and Development 29(4):1065-1073. https://doi.org/10.1002/Idr.2780

Abdel-Latef AA (2003). Response of some sorghum cultivars to salt stress and hormonal treatment. MSc Thesis, South Valley University, Qena, Egypt.

Adam A, Farkas T, Somlyai G, Hevesi M, Kiraly Z (1989). Consequence of $\mathrm{O}_{2}{ }^{-{ }^{-}}$generation during a bacterially induced hypersensitive reaction in tobacco: deterioration of membrane lipids. Physiological and Molecular Plant Pathology 34(1):13-26. https://doi.org/10.1016/0885-5765(89)90013-1

Aebi H (1984). Catalase in vitro. Methods in Enzymology 121-126. https://doi.org/10.1016/s0076-6879(84)05016-3

Ahmad B, Zaid A, Sadiq Y, Bashir S, Wani SH (2019). Role of selective exogenous elicitors in plants responses to abiotic stress tolerance. In: Hasanuzzaman M, Hakeem K, Nahar Kalharby H (Eds). Plant Abiotic Tolerance. https://doi.org/10.1007978-3-030-06118-0_12

Ahmad R, Hussain S, Anjum MA, Khalid MF, Saqib M, Zakir I, ... Ahmad S (2019). Oxidative stress and antioxidant defense mechanisms in plants under salt stress. Plant Abiotic Stress Tolerance 191-205. https://doi.org/10.1007/978-3-030-06118-0_8

Akram R, Fahad S, Masood N, Rasool A, Ijaz M, Ihsan MZ, ... Ahmed M (2019). Plant growth and morphological changes in rice under abiotic stress. Advances in Rice Research for Abiotic Stress Tolerance 69-85. https://doi.org/10.1016/b978-0-12-814332-2.00004-6

Anuradha S, Rao SSR (2001). Effect of brassinosteroids on salinity stress induced inhibition of seed germination and seedling growth of rice (Oryza sativa L.). Plant Growth Regulation 33(2):151-153. https://doi.org/10.1023/a:1017590108484

Assaha DV, Ueda A, Saneoka H, Al-Yahyai R, Yaish MW (2017). The role of $\mathrm{Na}^{+}$and $\mathrm{K}^{+}$transporters in salt stress adaptation in glycophytes. Frontiers in Physiology 8:509. https://doi.org/10.3389/fphys.2017.00509

Attia MS, Osman MS, Mohamed AS, Mahgoub HA, Garada MO, Abdelmouty ES, Abdel Latef AA (2021). Impact of foliar application of chitosan dissolved in different organic acids on isozymes, protein patterns and physiobiochemical characteristics of tomato grown under salinity stress. Plants 10:388.

https://doi.org/10.3390/plants10020388

Azooz M, Shaddad M, Abdel-Latef A (2004a). The accumulation and compartmentation of proline in relation to salt tolerance of three sorghum cultivars. Indian Journal of Plant Physiology. Indian Society for Plant Physiology 9:18. https://doi.org/10.1556/aagr.52.2004.3.10

Azooz M, Shaddad M, Abdel-Latef A (2004b). Leaf growth and $\mathrm{K}^{+} / \mathrm{Na}^{+}$ratio as an indication of the salt tolerance of three sorghum cultivars grown under salinity stress and IAA treatment. Acta Agronomica Hungarica 52(3):287-296. https://doi.org/10.1556/aagr.52.2004.3.10

Bandurska H, Niedziela J, Pietrowska-Borek M, Nuc K, Chadzinikolau T, Radzikowska D (2017). Regulation of proline biosynthesis and resistance to drought stress in two barley (Hordeum vulgare L.) genotypes of different origin. Plant Physiology and Biochemistry 118:427-437. https://doi.org/10.1016/j.plaphy.2017.07.006

Bates LS, Waldren RP, Teare I (1973). Rapid determination of free proline for water-stress studies. Plant and Soil 39(1):205-207. https://doi.org/10.1007/bf00018060

Bin T, Xu S-Z, Zou X-L, Zheng Y-L, Qiu F-Z (2010). Changes of antioxidative enzymes and lipid peroxidation in leaves and roots of waterlogging-tolerant and waterlogging-sensitive maize genotypes at seedling stage. Agricultural Sciences in China 9(5):651-661. https://doi.org/10.1016/s1671-2927(09)60140-1

Chen F, Wang F, Sun H, Cai Y, Mao W, Zhang G, Vincze E, Wu F (2010). Genotype-dependent effect of exogenous nitric oxide on $\mathrm{Cd}$-induced changes in antioxidative metabolism, ultrastructure, and photosynthetic performance 
in barley seedlings (Hordeum vulgare). Journal of Plant Growth Regulation 29(4):394-408. https://doi.org/10.1007/s00344-010-9151-2

Chen G-X, Asada K (1992). Inactivation of ascorbate peroxidase by thiols requires hydrogen peroxide. Plant and Cell Physiology 33(2):117-123. https://doi.org/10.1093/oxfordjournals.pcp.a078229

Dawood MFA, Sohag AAM, Tahjib-Ul-Arif M, Abdel Latef AA (2021). Hydrogen sulfide priming can enhance the tolerance of artichoke seedlings to individual and combined saline-alkaline and aniline stresses. Plant Physiology and Biochemestry 159:347-362. https://doi.org/10.1016/j.plaphy.2020.12.034

Dbira S, Al Hassan M, Gramazio P, Ferchichi A, Vicente O, Prohens J, Boscaiu M (2018). Variable levels of tolerance to water stress (drought) and associated biochemical markers in Tunisian barley landraces. Molecules 23(3):613. https://doi.org/10.3390/molecules23030613

DESA U (2015). World population prospects: The 2015 revision, key findings and advance tables. United Nations Department of Economic and Social Affairs. Population Division working paper no. ESA/P/WP, 241. Retrieved 2020 September 12 from https://population.un.org/wpp/publication/files/key_findings_wpp_2015.pdf

Ding S, Ma C, Shi W, Liu W, Lu Y, Liu Q, Luo Z-B (2017). Exogenous glutathione enhances cadmium accumulation and alleviates its toxicity in Populus $\times$ canescens. Tree Physiology 37(12):1697-1712. https://doi.org/10.1093/treephys/tpx132

Engwa GA (2018). Free radicals and the role of plant phytochemicals as antioxidants against oxidative stress-related diseases. Phytochemicals: source of antioxidants and role in disease prevention. IntechOpen 49-73. https://doi.org/10.5772/intechopen.76719

Faghih S, Ghobadi C, Zarei A (2017). Response of strawberry plant cv. 'Camarosa' to salicylic acid and methyl jasmonate application under salt stress condition. Journal of Plant Growth Regulation 36(3):651-659. https://doi.org/10.1007/s00344-017-9666-X

Fahad S, Hussain S, Matloob A, Khan FA, Khaliq A, Saud S, ... Ullah N (2015). Phytohormones and plant responses to salinity stress: a review. Plant Growth Regulation 75(2):391-404. https://doi.org/10.1007/s10725-014-0013-y

Fales FW (1951). The assimilation and degradation of carbohydrates by yeast cells. Journal of Biological Chemistry 193(1):113-124. https://www.jbc.org/content/193/1/133.full.pdf

Fan H-F, Du C-X, Guo S-R (2012). Effect of nitric oxide on proline metabolism in cucumber seedlings under salinity stress. Journal of the American Society for Horticultural Science 137(3):127-133. https://doi.org/10.21273/jashs.137.3.127

Fariduddin Q, Zaid A, Mohammad F (2019). Plant growth regulators and salt stress: Mechanism of tolerance trade-off. In: Akhter M (Ed). Salt Stress, Microbes and Plant Interactions: Causes and Solution. https://doi.org/10.1007/978-981-13-8801-9_4

Fu R, Zhang M, Zhao Y, He X, Ding C, Wang S, ... Wang B (2017). Identification of salt tolerance-related microRNAs and their targets in maize (Zea mays L.) using high-throughput sequencing and degradome analysis. Frontiers in Plant Science 8:864. https://doi.org/10.3389/fpls.2017.00864

Geist H (2017). The causes and progression of desertification. Routledge. https://doi.org/10.4324/9781315240855

Giménez M, Drago S, De Greef D, Gonzalez R, Lobo M, Samman N (2012). Rheological, functional and nutritional properties of wheat/broad bean (Vicia faba) flour blends for pasta formulation. Food Chemistry 134(1):200-206. https://doi.org/10.1016/j.foodchem.2012.02.093

Guo W (2017) Magnesium homeostasis mechanisms and magnesium use efficiency in plants. In: Plant Macronutrient Use Efficiency. Academic Press, pp 197-213. https://doi.org/10.1016/b978-0-12-811308-0.00011-9

Gurmani A, Bano A, Salim M (2007). Effect of abscisic acid and benzyladenine on growth and ion accumulation of wheat under salinity stress. Pakistan Journal of Botany 39(1):141.

Hadiarto T, Tran L-SP (2011). Progress studies of drought-responsive genes in rice. Plant Cell Reports 30(3):297-310. https://doi.org/10.1007/s00299-010-0956-Z

Hakim M, Juraimi A, Hanafi M, Ismail M, Rafii M, Islam M, Selamat A (2014). The effect of salinity on growth, ion accumulation and yield of rice varieties. Journal of Animal and Plant Science 24(3):874-885.

Hanin M, Ebel C, Ngom M, Laplaze L, Masmoudi K (2016). New insights on plant salt tolerance mechanisms and their potential use for breeding. Frontiers in Plant Science 7:1787. https://doi.org/10.3389/fpls.2016.01787

Hasanuzzaman M, Anee TI, Bhuiyan TF, Nahar K, Fujita M (2019). Emerging role of osmolytes in enhancing abiotic stress tolerance in rice. Advances in Rice Research for Abiotic Stress Tolerance 677-708. https://doi.org/10.1016/b978-0-12-814332-2.00033-2 
Hawrylak-Nowak B (2013). Comparative effects of selenite and selenate on growth and selenium accumulation in lettuce plants under hydroponic conditions. Plant Growth Regulation 70(2):149-157.

https://doi.org/10.1007/s10725-013-9788-5

Heath RL, Packer L (1968). Photoperoxidation in isolated chloroplasts: I. Kinetics and stoichiometry of fatty acid peroxidation. Archives of Biochemistry and Biophysics 125(1):189-198. https://doi.org/10.1016/0003-9861(68)90654-1

Hu J, Ren B, Dong S, Liu P, Zhao B, Zhang J (2020). Comparative proteomic analysis reveals that exogenous 6benzyladenine (6-BA) improves the defense system activity of waterlogged summer maize. BMC Plant Biology 20(1):44. https://doi.org/10.1186/s12870-020-2261-5

Iqbal M, Ashraf M, Jamil A (2006). Seed enhancement with cytokinins: changes in growth and grain yield in salt stressed wheat plants. Plant Growth Regulation 50(1):29-39. https://doi.org/10.1007/s10725-006-9123-5

Javid MG, Sorooshzadeh A, Moradi F, Modarres Sanavy SAM, Allahdadi I (2011a). The role of phytohormones in alleviating salt stress in crop plants. Australian Journal of Crop Science 5(6):726.

Javid MG, Sorooshzadeh A, Sanavy SAMM, Allahdadi I, Moradi F (2011b). Effects of the exogenous application of auxin and cytokinin on carbohydrate accumulation in grains of rice under salt stress. Plant Growth Regulation 65(2):305-313. https://doi.org/10.1007/s10725-011-9602-1

Jiang J-L, Tian Y, Li L, Yu M, Hou R-P, Ren X-M (2019). H2S alleviates salinity stress in cucumber by maintaining the $\mathrm{Na}^{+} / \mathrm{K}^{+}$balance and regulating $\mathrm{H} 2 \mathrm{~S}$ metabolism and oxidative stress response. Frontiers in Plant Science 10:678. https://doi.org/10.3389/fpls.2019.00678

Khan A, Pan X, Najeeb U, Tan DKY, Fahad S, Zahoor R, Luo H (2018). Coping with drought: stress and adaptive mechanisms, and management through cultural and molecular alternatives in cotton as vital constituents for plant stress resilience and fitness. Biological Research 51(1):47. https://doi.org/10.1186/s40659-018-0198-Z

Khan MN, Zhang J, Luo T, Liu J, Ni F, Rizwan M, Fahad S, Hu L (2019a). Morpho-physiological and biochemical responses of tolerant and sensitive rapeseed cultivars to drought stress during early seedling growth stage. Acta Physiologiae Plantarum 41(2):25. https://doi.org/10.1007/s11738-019-2812-2

Khan N, Bano A, Rahman MA, Rathinasabapathi B, Babar MA (2019b). UPLC-HRMS-based untargeted metabolic profiling reveals changes in chickpea (Cicer arietinum) metabolome following long-term drought stress. Plant, Cell \& Environment 42(1):115-132. https://doi.org/10.1111/pce.13195

Klapheck S, Zimmer I, Cosse H (1990). Scavenging of hydrogen peroxide in the endosperm of Ricinus communis by ascorbate peroxidase. Plant and Cell Physiology 31(7):1005-1013. https://doi.org/10.1093/oxfordjournals.pcp.a077996

Lowry OH, Rosebrough NJ, Farr AL, Randall RJ (1951). Protein measurement with the Folin phenol reagent. Journal of Biological Chemistry 193:265-275.

Ma L, Li Y, Yu C, Wang Y, Li X, Li N, Chen Q, Bu N (2012). Alleviation of exogenous oligochitosan on wheat seedlings growth under salt stress. Protoplasma 249(2):393-399. https://doi.org/10.1007/s00709-011-0290-5

Maehly A, Chance B (1954). Catalases and peroxidases. Methods of Biochemical Analysis 1:357-424. https://doi.org/10.1002/9780470110171.ch14

Mahdi AHA, Badawy SA, Abdel Latef AA, El Hosary AAA, Abd El Razek UA, Taha RS (2021). Integrated effects of potassium humate and planting density on growth, physiological traits and yield of Vicia faba L. grown in newly reclaimed soil. Agronomy 11:461. https://doi.org/10.3390/agronomy11030461

Mahmud S, Sharmin S, Chowdhury BLD, Hossain MA (2017). Effect of salinity and alleviating role of methyl jasmonate in some rice varieties. Asian Journal of Plant Sciences 16(2):87-93. https://doi.org/10.3923/ajps.2017.87.93

Mansour MMF, Ali EF (2017). Evaluation of proline functions in saline conditions. Phytochemistry 140:52-68. https://doi.org/10.1016/j.phytochem.2017.04.016

Mbarki S, Sytar O, Cerda A, Zivcak M, Rastogi A, He X, Zoghlami A, Abdelly C, Brestic M (2018). Strategies to mitigate the salt stress effects on photosynthetic apparatus and productivity of crop plants. Salinity Responses and Tolerance in Plants 1:85-136. https://doi.org/10.1007/978-3-319-75671-4_4

Miller G, Suzuki N, Ciftci-Yilmaz S, Mittler R (2010). Reactive oxygen species homeostasis and signalling during drought and salinity stresses. Plant, Cell \& Environment 33(4):453-467. https://doi.org/10.1111/j.1365-3040.2009.02041.x

Mittler R (2002). Oxidative stress, antioxidants and stress tolerance. Trends in Plant Science 7(9):405-410. https://doi.org/10.1016/s1360-1385(02)02312-9 
Moore S, Stein WH (1948). Photometric nin-hydrin method for use in the ehromatography of amino acids. Journal of Biological Chemistry 176:367-388.

Morton MJ, Awlia M, Al-Tamimi N, Saade S, Pailles Y, NegrãoS, Tester M (2019). Salt stress under the scalpel-dissecting the genetics of salt tolerance. The Plant Journal 97(1):148-163. https://doi.org/10.1111/tpj.14189

Mostofa MG, Rahman A, Ansary MMU, Watanabe A, Fujita M, Tran L-SP (2015). Hydrogen sulfide modulates cadmium-induced physiological and biochemical responses to alleviate cadmium toxicity in rice. Scientific Reports 5(1):1-17. https://doi.org/10.1038/srep14078

Mukherjee S, Choudhuri M (1983). Implications of water stress-induced changes in the levels of endogenous ascorbic acid and hydrogen peroxide in Vigna seedlings. Physiologia Plantarum 58(2):166-170. https://doi.org/10.1111/j.1399-3054.1983.tb04162.x

Munns R, Tester M (2008). Mechanisms of salinity tolerance. Annual Review of Plant Biology Annual Reviews 59:651681. https://doi.org/10.1146/annurev.arplant.59.032607.092911

Nachshon U (2018). Cropland soil salinization and associated hydrology: Trends, processes and examples. Water 10(8):1030. https://doi.org/10.3390/w10081030

Nadeem M, Li J, Yahya M, Sher A, Ma C, Wang X, Qiu L (2019). Research progress and perspective on drought stress in legumes: A review. International Journal of Molecular Sciences 20(10):2541. https://doi.org/10.3390/ijms20102541

Nawaz F, Ahmad R, Ashraf M, Waraich E, Khan S (2015). Effect of selenium foliar spray on physiological and biochemical processes and chemical constituents of wheat under drought stress. Ecotoxicology and Environmental Safety 113:191-200. https://doi.org/10.1016/j.ecoenv.2014.12.003

Noreen S, Sultan M, Akhter MS, Shah KH, Ummara U, Manzoor H, Ulfat M, Alyemeni MN, Ahmad P (2020). Foliar Fertigation of ascorbic acid and zinc improves growth, antioxidant enzyme activity and harvest index in barley (Hordeum vulgare L.) grown under salt stress. Plant Physiology and Biochemistry https://doi.org/10.1016/j.plaphy.2020.11.007

Orlovsky N, Japakova U, Zhang H, Volis S (2016). Effect of salinity on seed germination, growth and ion content in dimorphic seeds of Salicornia europaea L. (Chenopodiaceae). Plant Diversity 38(4):183-189. https://doi.org/10.1016/j.pld.2016.06.005

Osman MS, Badawy AA, Osman AI, Latef AAHA (2020). Ameliorative impact of an extract of the halophyte Arthrocnemum macrostachyum on growth and biochemical parameters of soybean under salinity stress. Journal of Plant Growth Regulation 1-12. https://doi.org/10.1007/s00344-020-10185-2

Öztürk M (2012). Anticholinesterase and antioxidant activities of Savoury (Satureja thymbra L.) with identified major terpenes of the essential oil. Food Chemistry 134(1):48-54. https://doi.org/10.1016/j.foodchem.2012.02.054

Parida AK, Veerabathini SK, Kumari A, Agarwal PK (2016). Physiological, anatomical and metabolic implications of salt tolerance in the halophyte Salvadora persica under hydroponic culture condition. Frontiers in Plant Science 7:351. https://doi.org/10.3389/fpls.2016.00351

Rahman M, Mostofa MG, Keya SS, Rahman A, Das AK, Islam R, Abdelrahman M, Bhuiyan SU, Naznin T, Ansary MU (2020). Acetic acid improves drought acclimation in soybean: an integrative response of photosynthesis, osmoregulation, mineral uptake and antioxidant defense. Physiologia Plantarum https://doi.org/10.1111/ppl.13124

Rahman MM, Mostofa MG, Rahman MA, Islam MR, Keya SS, Das AK, Miah MG, Kawser AR, Ahsan S, Hashem A (2019). Acetic acid: a cost-effective agent for mitigation of seawater-induced salt toxicity in mung bean. Scientific reports 9(1):1-15. https://doi.org/10.1038/s41598-019-51178-W

Raikos V, Neacsu M, Russell W, Duthie G (2014). Comparative study of the functional properties of lupin, green pea, fava bean, hemp, and buckwheat flours as affected by pH. Food Science \& Nutrition 2(6):802-810. https://doi.org/10.1002/fsn3.143

Rehman S, Abbas G, Shahid M, Saqib M, Farooq ABU, Hussain M, ... Farooq A (2019). Effect of salinity on cadmium tolerance, ionic homeostasis and oxidative stress responses in conocarpus exposed to cadmium stress: Implications for phytoremediation. Ecotoxicology and Environmental Safety 171:146-153. https://doi.org/10.1016/j.ecoenv.2018.12.077

Ren B, Zhang J, Dong S, Liu P, Zhao B (2017). Regulations of 6-benzyladenine (6-BA) on leaf ultrastructure and photosynthetic characteristics of waterlogged summer maize. Journal of Plant Growth Regulation 36(3):743-754. https://doi.org/10.1007/s00344-017-9677-7 
Ren C-G, Kong C-C, Xie Z-H (2018). Role of abscisic acid in strigolactone-induced salt stress tolerance in arbuscular mycorrhizal Sesbania cannabina seedlings. BMC Plant Biology 18(1):1-10. https://doi.org/10.1186/s12870-0181292-7

Roy PR, Tahjib-Ul-Arif M, Polash MAS, Hossen MZ, Hossain MA (2019). Physiological mechanisms of exogenous calcium on alleviating salinity-induced stress in rice (Oryza sativa L.). Physiology and Molecular Biology of Plants 25(3):611-624. https://doi.org/10.1007/s12298-019-00654-8

Scebba F, Sebastiani L, Vitagliano C (1999). Protective enzymes against activated oxygen species in wheat (Triticum aestivum L.) seedlings: responses to cold acclimation. Journal of Plant Physiology 155(6):762-768. https://doi.org/10.1016/s0176-1617(99)80094-7

Schwarzenbach G, Biedermann W (1948). Komplexone X. Erdalkalikomplexe von o, o'-Dioxyazofarbstoffen. Helvetica Chimica Acta 31(3):67-687. https://doi.org/10.1002/hlca.19480310303

Shah S (2011). Kinetin improves photosynthetic and antioxidant responses of Nigella sativa to counteract salt stress. Russian Journal of Plant Physiology 58(3):454-459. https://doi.org/10.1134/s1021443711030150

Sharma N, Singh N, Singh O, Pandey V, Verma P (2011). Oxidative stress and antioxidant status during transition period in dairy cows. Asian-Australasian Journal of Animal Sciences 24(4):479-484. https://doi.org/10.5713/ajas.2011.10220

Shrivastava P, Kumar R (2015). Soil salinity: a serious environmental issue and plant growth promoting bacteria as one of the tools for its alleviation. Saudi Journal of Biological Sciences 22(2):123-131. https://doi.org/10.1016/j.sjbs.2014.12.001

Siddiqui MN, Mostofa MG, Akter MM, Srivastava AK, Sayed MA, Hasan MS, Tran L-SP (2017). Impact of salt-induced toxicity on growth and yield-potential of local wheat cultivars: oxidative stress and ion toxicity are among the major $\begin{array}{lllll}\text { determinants of } & \text { salt-tolerant } & \text { capacity. }\end{array}$ https://doi.org/10.1016/j.chemosphere.2017.08.078

Singh AK, Bharati R, Pedpati A (2013). An assessment of faba bean (Vicia faba L.) current status and future prospect. African Journal of Agricultural Research 8(50):6634-6641. https://doi.org/10.5897/ajar2013.7335

Singh M, Singh A, Prasad SM, Singh RK (2017). Regulation of plants metabolism in response to salt stress: an omics approach. Acta Physiologiae Plantarum 39(2):48. https://doi.org/10.1007/s11738-016-2345-X

Sohag AAM, Tahjib-Ul-Arif M, Brestic M, Afrin S, Sakil MA, Hossain MT, ... Hossain MA (2020a). Exogenous salicylic acid and hydrogen peroxide attenuate drought stress in rice. Plant, Soil and Environment 66(1):7-13. https://doi.org/10.17221/472/2019-pse

Sohag AAM, Tahjib-Ul-Arif M, Polash MAS, Chowdhury MB, Afrin S, Burritt DJ, ... Hossain MA (2020b). Exogenous glutathione-mediated drought stress tolerance in rice (Oryza sativa L.) is associated with lower oxidative damage and favorable ionic homeostasis. Iranian Journal of Science and Technology 44(4):955-971. https://doi.org/10.1007/s40995-020-00917-0

Soundararajan P, Manivannan A, Ko CH, Jeong BR (2018). Silicon enhanced redox homeostasis and protein expression to mitigate the salinity stress in Rosa hybrida 'Rock Fire.' Journal of Plant Growth Regulation 37(1):16-34. https://doi.org/10.1007/s00344-017-9705-7

Tahjib-Ul-Arif M, Sayed MA, Islam MM, Siddiqui MN, Begum S, Hossain MA (2018a). Screening of rice landraces (Oryza sativa L.) for seedling stage salinity tolerance using morpho-physiological and molecular markers. Acta Physiologiae Plantarum 40(4):70. https://doi.org/10.1007/s11738-018-2645-4

Tahjib-Ul-Arif M, Siddiqui MN, Sohag AAM, Sakil MA, Rahman MM, Polash MAS, ... Tran L-SP (2018b). Salicylic acid-mediated enhancement of photosynthesis attributes and antioxidant capacity contributes to yield improvement of maize plants under salt stress. Journal of Plant Growth Regulation 37(4):1318-1330. https://doi.org/10.1007/s00344-018-9867-y

Tang X, Mu X, Shao H, Wang H, Brestic M (2015). Global plant-responding mechanisms to salt stress: physiological and molecular levels and implications in biotechnology. Critical Reviews in Biotechnology 35(4):425-437. https://doi.org/10.3109/07388551.2014.889080

Tanveer M, Shabala S. 2018. Targeting redox regulatory mechanisms for salinity stress tolerance in crops. Salinity Responses and Tolerance in Plants 1:213-234. https://doi.org/10.1007/978-3-319-75671-4_8

Uddin M, Juraimi AS, Ismail M, Hossain M, Othman R, Abdul Rahim A (2012). Physiological and growth responses of six turfgrass species relative to salinity tolerance. The Scientific World Journal 1-10 https://doi.org/10.1100/2012/905468 
Wang W, Xu Y, Chen T, Xing L, Xu K, Ji D, Chen C, Xie C (2019). Regulatory mechanisms underlying the maintenance of homeostasis in Pyropia haitanensis under hypersaline stress conditions. Science of the Total Environment 662:168-179. https://doi.org/10.1016/j.scitotenv.2019.01.214

Wang Y, Reiter RJ, Chan Z (2018). Phytomelatonin: a universal abiotic stress regulator. Journal of Experimental Botany 69(5):963-974. https://doi.org/10.1093/jxb/erx473

Weisany W, Sohrabi Y, Heidari G, Siosemardeh A, Ghassemi-Golezani K (2012). Changes in antioxidant enzymes activity and plant performance by salinity stress and zinc application in soybean (Glycine max L.). Plant Omics 5(2):60. https://www.pomics.com/sohrabi_5_2_2012_60_67.pdf

Williams V, Twine S (1960). Flame photometric method for sodium, potassium and calcium. Modern Methods of Plant Analysis 5:3-5.

Wu X, He J, Chen J, Yang S, Zha D (2014). Alleviation of exogenous 6-benzyladenine on two genotypes of eggplant (Solanum melongena Mill.) growth under salt stress. Protoplasma 251(1):169-176. https://doi.org/10.1007/s00709-013-0535-6

Xiaotao D, Yuping J, Hong W, Haijun J, Hongmei Z, Chunhong C, Jizhu Y (2013). Effects of cytokinin on photosynthetic gas exchange, chlorophyll fluorescence parameters, antioxidative system and carbohydrate accumulation in cucumber (Cucumis sativus L.) under low light. Acta Physiologiae Plantarum 35(5):1427-1438. https://doi.org/10.1007/s11738-012-1182-9

Yan Z, Ming D, Cui J, Chen X, Wen Z, Zhang J, Liu H (2018). Exogenous GSH protects tomatoes against salt stress by modulating photosystem II efficiency, absorbed light allocation and $\mathrm{H}_{2} \mathrm{O}_{2}$-scavenging system in chloroplasts. Journal of Integrative Agriculture 17(10):2257-2272. https://doi.org/10.1016/s2095-3119(18)62068-4

Yang Y, Guo Y (2018). Elucidating the molecular mechanisms mediating plant salt-stress responses. New Phytologist 217(2):523-539. https://doi.org/10.1111/nph.14920

Zulfiqar F, Akram NA, Ashraf M (2020). Osmoprotection in plants under abiotic stresses: new insights into a classical phenomenon. Planta 251(1):3. https://doi.org/10.1007/s00425-019-03293-1
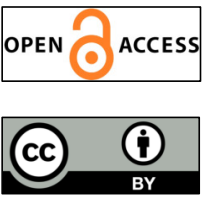

The journal offers free, immediate, and unrestricted access to peer-reviewed research and scholarly work. Users are allowed to read, download, copy, distribute, print, search, or link to the full texts of the articles, or use them for any other lawful purpose, without asking prior permission from the publisher or the author.

License - Articles published in Notulae Botanicae Horti Agrobotanici Cluj-Napoca are Open-Access, distributed under the terms and conditions of the Creative Commons Attribution (CC BY 4.0) License.

(C) Articles by the authors; UASVM, Cluj-Napoca, Romania. The journal allows the author(s) to hold the copyright/to retain publishing rights without restriction. 